\title{
Local Participatory Flood Hazard Mapping's Assessment and Coping: A Conceptual Model of Sustainability in Downstream Area of Belu Regency in the Western Timor Island, East Nusa Tenggara Province, Indonesia
}

\author{
Apolonia Diana Sherly da Costa ${ }^{1,2,3}$ \\ ${ }^{1}$ Master Program in Environment and Urban Studies, Catholic University of Soegijapranata, Semarang City, \\ Indonesia \\ ${ }^{2}$ Resilience for Sustainable Development-Based Environment (RESUDENVI), A Community Initiative Local \\ Program in Malaka District, Western Timor Island, East Nusa Tenggara Province, Indonesia \\ ${ }^{3}$ Department of Environment and Planning, Universidade de Aveiro, Aveiro City, Portugal \\ Correspondence: Apolonia Diana Sherly da Costa M.Sc, Ph.D, Lecturer and Researcher at Master Program in \\ Environment and Urban Studies, Catholic University of Soegijapranata, Semarang City, Indonesia; Founder and \\ Director RESUDENVI, A Community Initiative Local Program in Malaka District, Western Timor Island, East \\ Nusa Tenggara Province, Indonesia; and Postdoctorate Fellow at Department of Environment and Planning, \\ Universidade de Aveiro, Aveiro City, Portugal. Tel: 351-9-3863-4015. E-mail: sherly.dacosta@unika.ac.id; \\ resudenvicommunity@yahoo.com; apoloniadcosta@ua.pt; noidacosta_baucau@yahoo.co.id
}

Received: January 6, 2021

doi:10.5539/jsd.v14n2p38
Accepted: February 8, $2021 \quad$ Online Published: February 12, 2021

URL: https://doi.org/10.5539/jsd.v14n2p38

\begin{abstract}
This study applies interview, Focus Group Discussion (FGDs), Participatory Geographical Information Systems (pGIS), and a conceptual model of sustainability (CMS) using risk perception of local community to map flood hazard and assess the social and cultural copings to cope with river flooding in downstream areas i.e., Lasaen, Umatoos, and Fafoe villages of West Malaka Subdistrict of Belu Regency, Indonesia. The results of this study indicate that the rural-river flooding was inundated at all three villages. The cycle of flood is twenty-years per event (1939, 1959, 1975, 1999 through 2000), and from 2000 its occurrence was each year until 2012. Based on interviews and FGDs, the information of flood characteristics of Lasaen and Fafoe villages were similar, but Umatoos village was not. The single longevity of flood inundation was in Fafoe village (1 week-1 month). Whilst Lasaen and Umatoos villages were experiencing less duration of flood inundations ( $0-7$ days to 14-21 days). Lasaen and Umatoos Villages were dealing with flood depth's variation from the lowest depth $(0-50 \mathrm{~cm})$ to its deepest $(251-300 \mathrm{~cm})$. For CMS, the most invaluable coping that might be sustainable was cultural capital. Both social and cultural coping enhancements were implemented by local community. The minimum and lack of both these transformable sub-copings were still the problem in the discourse unit of sustainability. As each sub-coping would be overlapped if there has no sufficient distribution of it, utilized by the local community. The genuineness local knowledge of community in applying their social and cultural copings in sustainability is seen as a unique reference and a useful form of local wisdom which can be highlighted and adopted as an effective and/or example discourse analysis by the other rural villages in developing nations that are also still struggling and coping with flood disaster.
\end{abstract}

Keywords: assessment, conceptual model of sustainability (CMS), coping, focus group discussion (FGDs), flood hazard mapping, interview, participatory geographical information systems (pGIS), and risk perception

\section{Introduction}

Global statistics show that floods are the most frequently recorded destructive events, accounting for about thirty percent of the world's disasters each year where the frequency of floods is increasing faster than in any other type of disaster (Medscape, 2005). Flood has impacted social disruptions and many aspects of life and led to environmental problems. Andriyani et al., (2010) revealed that the floods represent the part of environmental problems of physical on the surface of earth resulting loss and can be interpreted a situation where irrigate river 
abundance, suffusing area of around it until certain deepness till generate loss. Not only social aspect is at risk, caused by flood disaster but also infrastructure or physical aspect. The impact of flooding can include destruction of housing, crops, cattle and people (International Federation of Red Cross and Red Crescent Societies or IFRC, 2011). The occurrence of system communication barriers between affected communities has also become a problem of flood disaster which often occur where risk communication with the use of risk perception needs to be studied. Flooding causes few deaths, instead, widespread and long-lasting detrimental effects include mass homelessness, disruption of communications and health care systems, and heavy loss of business, livestock, crops, and grain, particularly in densely-populated, low lying areas (Medscape, 2005). This research investigates the empirical assessment and discussion about flood hazard mapping and coping as well as discourse of sustainability coping for rural-river flood disaster in the research site. It is noticeable that there were no previous researchers from private and public Institutions at the local, regional, national, and international levels that have ever done this empirical research. Riverine flooding occurs when the volume of water in a river exceeds local capacity. The scale, frequency, intensity and duration of floods generally depend on the hydro-meteorological events that drive these events and the hydrological characteristics of the catchment, and the capacity of the natural drainage facilities in each region (The World Meteorological Organization or WMO and The Global Water Partnership or GWP in The Associated Programme on Flood Management or APFM, 2008 p.2). In this research, rural-river flood disaster is understood or known more prominently as "flood disaster for remote communities" with the unique coping processes and actions that focus more on social and cultural values, and human-social geographic analysis in the discourse of sustainability coping. From twenty-third provinces/regions of the index of prone single hazard that vulnerable to floods by 2011, it was informed that Belu Regency of the Western Timor Island, East Nusa Tenggara Province, Indonesia gets a high class of flood's hazard with the score of 54, and sits 21 of the Indonesian national ranking (The National Body of Disaster Management (Badan Nasional Penanggulangan Bencana or BNPB, 2011)). Meanwhile, the terms "urban" and "rural" are used in different contexts with more or less precision. Policy makers and planners need to get a better understanding of how flooding impacts on communities with particular characteristics, going beyond some familiar stereotypes about the nature of urban and rural areas and looking at social trends such as migration out of cities and within urban areas (Environmental Agency British Government 2005 p.1). Indeed, every remote community who is affected by rural-river flooding is relied more on key local stakeholders and local leaders at their village as less decision support they received from the policy makers and planners. Thus, it is important to discuss socio-cultural copings in the discourse of sustainability. In specific analysis on this research, the assessment of flood management in rural areas consists of inter-cross, and trans-sectors' connections and discussions of the local community copings that are resilient and have been developed an influential manner on the values of their civilization and local socio-cultural adjustment in the daily practices. However, it is confirmed in this research that neither economic sector nor economic policy discussion is majorly included or at the core analysis, rather social and cultural copings. Several discussions and findings that were dealt with rural flooding were almost solving the risk and livestock of local people. For instance, the headline news of the United Nations World Food Programme (WFP) which was about the topic, entitled "In Flood-Affected Rural Areas, Poorest People Face Highest Food Insecurity Risk and Livestock and Fisheries Sectors yet to Recover from Severe Damage", a rural-flooding in Myanmar, posted in 17 March 2016 (WFP's News, 2016). There are not many previous studies from previous researchers in interdisciplinary studies of the environment and human geography in developing countries who observed and conducted sustainability coping studies for mapping rural flood hazards based on key local stakeholders' perceptions. Most previous and current studies on sustainable flood management's aim was to draw the intrinsic values were built up by the community, however these were not able comprehensively changing the adjustment and practical actions of copings that community does to deal with flood disaster in the long run, and were still only at the systematic, complex, and application method of measurement or engineering calculations. This research established a new refreshment idea about sustainability of social and cultural copings and flood hazard mapping and assessment of local community who faces rural-river flooding based on local knowledge of community in the most affected villages by rural-river flooding in Belu Regency, Western Timor Island, East Nusa Tenggara Province, Indonesia i.e., Lasaen, Umatoos, and Fafoe.

This research tends to use the risk perception from the local people's knowledge rather than the contribution of theory and field data of the previous authors and researchers' reports, because this type of research is rarely found. The purpose of this research, is therefore, to assess and discuss about social and cultural copings assessment and resilience were integrated into the risk perception of local communities in understanding the flood characteristics in the research site. Community took initiative and independent actions that were built up by their everyday resilience, processes, and solutions. This action was then formed as their daily local knowledge which needs to be sharpened through a serious and a reflective joint discussion in the Focus Group Discussion (FGDs). Understanding changes in the long-term impacts of integrating social and cultural copings assessments and the 
characteristics of flood disasters in terms of their discussion using the conceptual model of sustainability (CMS) was believed by key local stakeholders themselves in the three villages, that it can be truly a valuable reference, for adjustment processes and even to change the social and cultural environmental impacts of the flood in the near future. Thus, this CMS has a long-term effect which was developed based on mutual agreement between author and them and themselves in assessing their own risk perception about assessment and copings of social and cultural aspects and flood characteristics. It is noticeable, mitigation, preparation and further development of resilience or copings for the case of rural flood disasters in other regions of global south can also apply this CMS, which is not always relied on the systematically, technically and quantitatively measurements as most previous researcher did; however, as it has unlimited value which is dynamic by changes and adjustments in every people and their social and cultural environments at the ex-post flood disaster in particular. Many technical applications for measuring flood disaster management focused on the environment, economy, social and education, but the criteria are more generally systematic-mathematic-countable based on researchers' reviews, and less specifically on impractical work based on joint reviews (researchers and participants). Meanwhile, the socio-ecological and cultural ecology systems, in terms of the environment affected by floods, have obviously a very prominent role and status of social and cultural understanding and communication among society in understanding and revealing what and how sustainability could be. The concept of sustainability that the author applies in this study is understood as a center and reference for joint achievements between author and participants who can effectively and sufficiently be used as a new foundation, and a further study data for local communities living in the downstream area of the river for flood disaster in order to together strengthen the coping system of social and cultural in adjustment processes for dealing with the barriers of characteristic of flood disaster.

This study applies a conceptual model of sustainability (CMS) that includes social and cultural copings based on community perceptions, represented by key local stakeholders in the FGDs. The discussion on the assessment of this duo copings in understanding each flood characteristic was expressed by the community, with critical studies related to sustainability values that were understood from the perspective of sociology and culture, as well as psychology and few perspectives of religion. This approach advances current local flood hazard mapping practices and improves sustainability risk reduction strategies that consider the environmental impacts of flooding simultaneously. This approach is indeed conceptual but very effective in the long term, because the results of the discussion of social and cultural copings' assessments are considered jointly, integrated, binding, comprehensionable, and effectively increasing awareness, mitigation, and are also able influencing other types of coping such as economic coping and health coping towards solving rural flood disaster problems at other remote villages in Indonesia and/or other developing nations.

\section{Research Site}

The research site is located at three most affected villages of river flooding in the West Malaka Subdistrict of Belu Regency, Western Timor Island, East Nusa Tenggara Province, Indonesia i.e., Lasaen, Umatoos and Fafoe. These three villages were impacted by the extreme flood for twenty return period and annual (each year) occurrences and were leading to loss and damage of the community's live and livelihood. Belu Regency is located at coordinates from $124^{\circ} 35^{\prime}$ until $126^{\circ} 12^{\prime}$ East Longitude and from $8^{\circ} 57^{\prime}$ until $9^{\circ} 49^{\prime}$ South Latitude. It has strategic position due it's location at the junction of Timor Leste with the state of another of East Nusa Tenggara Province and at intersections between East Flores and North Central of Timor.

Geographically, Benanain River is the biggest river that is located in Timor Islands includes three Districts administration and one neighbor's country, the boundaries are:

Northern: Ombai Strait

Southern: Timor Ocean

Eastern: State of Timor Leste (Republica democratica de Timor Leste)

Western: North Central of Timor and East South of Timor

The topography of Belu is indicated by flat area to rolling Hills Mountains to the Rivers which flows to north and south and followed by the direction of Rivers' slope, flow from the south and empties into the Ombai Strait and Timor Ocean (Info NTT, 2011). The research site i.e., Lasaen, Umatoos, and Fafoe villages is presented in this Figure 1. 


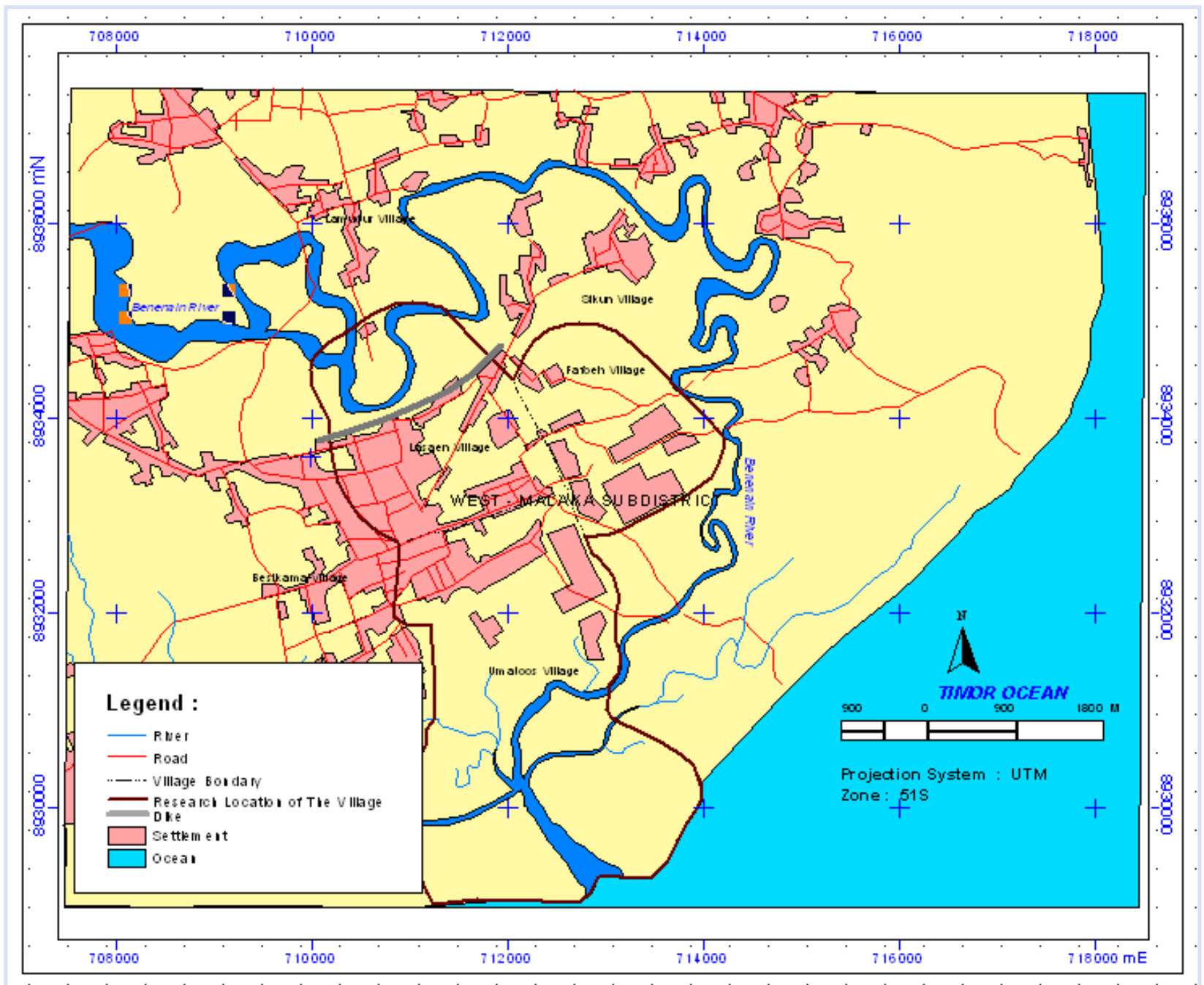

Figure 1. Research site (Lasaen, Umatoos, and Fafoe) villages

Source: Author‘s own map

\section{Research Method}

\subsection{Allure or Stage of Assessment and Copings}

The flow of assessment and copings of key local stakeholders, after interviews and FGDs, is the assessment and discussion of the CMS model (see Section 3.5, Figure 2 \& Section 4.4). In the interview stage, the author was conducted a field-survey and fieldwork to map the hazard locations or points (twenty affected households or families) in each of the three villages (Lasaen, Umatoos and Fafoe). Meanwhile, at the FGD stage, the results of the distribution of affected households were well created and provided in a printed map, with the additional equipment i.e., printed hazard location map, for applying the delineation and for determining information about flood characteristics based on local knowledge of key local stakeholders. In these two stages, this study has two main objectives to present their results (see results and discussion sections), namely (1) to map the hazard map based on the Participatory Geographical Information Systems (pGIS); and (2) to present local people's information and understanding about flood characteristics through the delineated map based on risk perception. Furthermore, in the assessment and copings stages, the CMS model is used as a reference for the assessment of environmental units and flood hazards which describe the form and pattern connectivity and quality of social and cultural copings based on cross-discipline and scientific terms in the conceptual presentation of CMS. By using the qualitative descriptive analysis, the four sub-questions of CMS' assessment are presented on this study.

\subsection{Survey and Interview}

Survey and interview were carried out in different research schedules. A survey of the research location was conducted three months earlier (the initial stage of the field-research that was done in May 2012). Its aim to 
understand the characteristics of the geographical area and local community's social and cultural geography and to establish communication with key local stakeholders in each village for joint agreement and exposure of determining the type of sampling, the selection of the most prone villages to river flooding and preparing the flood hazard map of the selected prone villages, located at the most downstream area of the Benanain river. Meanwhile, interviews were started from $31^{\text {st }}$ July to $31^{\text {st }}$ August 2012 (one month) at the research location using the chosen sampling i.e., purposive sampling, and with a questionnaire was prepared in Indonesian Language. Both survey and interviews have involved local community and key local stakeholder's cooperation and coordination in making conclusion of which type of sampling is suitable and appropriate to be used for interview. We agreed to choose purposive sampling as it purposively relies on author's point of view after understanding the characteristic of the local community and their area, the local knowledge of community who's adhered their trust to their female tribalchief and key local stakeholders. The form of trust that local community implemented was among others; (1) to be their leader (representative) in representing them for deciding important outcomes of a meeting, discussion, interview, and other crucial decisions regarding their resilience and hazard management respectively; and (2) to be their leader and guide in ensuring the information from their everyday-practice-communication both in the formal and informal (social) meeting was comprehensive to be delivered and understood for others including external society. This research paid attention on the fact that, of which village has a longest duration and the deepest inundation of flood disaster, evidenced by the inundation's mark from each household's house was inundated by flood disaster and that was disturbing their social, economic, and cultural daily activities.

\subsection{Focus Group Discussion (FGDs)}

Focus Group Discussion (FGD) is an effective method was used in this study in gathering community's data about flood's knowledge of characteristics that they need to understand to face flood disaster in 2012. Kumar, et al., (2010) revealed that Focus Group Discussion's information were fed into the study. This FGDs may discover important information about sustainable social and cultural copings for flood disaster by collecting the key local stakeholders' decision support. FGDs with men and women beneficiaries from communities (Shah, 2012). FGDs as a research method can be adopted by the government in a wider scope since it costs low budget and relatively effective in digging information of the flood perception and coping strategies of the local people to support the flood hazard management in the city (Febrianty, 2010). The total of interviewees in the study area (i.e., Lasaen, Umatoos and Fafoe) is 60 . Nevertheless, FGD in 3 villages were attended by different key local stakeholders. One village is taken from the head of the village (Rukun Tetangga or RT and Rukun Warga or RW) while the other is taken from the head of subvillage (dusun) or the leader of the community (Pamong adat) and the leader of Christian-Catholic religion in the study area. Prior to finalize the FGDs with key local stakeholders in the three villages, the GeoEye Satellite Image, 2012 was applied based on the village map that this research used in order to know the participants' local knowledge and understanding of the flood's characteristic (i.e., flood frequency, flood distribution or flood extent, water depth and flood duration). Key local stakeholders were asked to describe each elements of flood characteristic into three categorizations, they are low or quick, moderate/medium and deep or long. Their risk perception in determining the classification of each element of flood characteristics were varied to be found.

\subsection{FGDs and pGIS for Flood Characteristics using Risk Perception}

FGDs as a forum for key local stakeholders to gather and to counsel in the discussion (it is considerably thought as the way which help gain more collectively and mutually encouragement among each member during discussion and final decision making; result). FGD was carried out in Lasaen and Umatoos villages at outdoor (front yield of each village's leader house) while the discussion in Fafoe village was done at most flexible outdoor (sitting on the grass near to the leader of Fafoe village's agriculture land). The places of doing the FGDs were decided by each leader form these villages, as it was easier and more enjoyable to discuss about their risk perceptions of flood characteristics using pGIS. Meanwhile, the pGIS was used on the FGDs as a technical tool to express their risk perceptions which was derived from their own local knowledge in mapping the type or element of flood characteristics. Each discussion and result from FGDs and pGIS are presented in this section. Considering that this study area is a cultural, matrilineal, and sacred land, with a local leadership; a female tribal chief, then, risk perception in this study has its own definition for implementing the FGDs. Risk perception is defined by the community (represented by key local stakeholders during the FGDs) as the language of culture and local community's beliefs in expressing the facts and reasons about flooding and coping assessments that must rely on social and cultural aspects as the main strength or resilience in handling flood disaster. Thus, this definition of risk perception, which is discussed in this qualitative study, is therefore an appropriate conception to guide us in understanding the flow of the discussion and assessment of the entire study. 


\subsection{Conceptual Model of Sustainability (CMS)}

This conceptual model is a practical model that embraces various roles inter-across-trans-disciplines, is conceptualized or interpreted in complex and specific descriptions of related terms from social and cultural copings in a unitary environment and social-practical geography but focuses on one final goal that is the benefits of this model could therefore be useful implemented and sustained by local communities who deal with natural disaster in the long run. It can provide local understanding and the extent to which the interrelationships of the hazards or disasters faced by communities do not reduce resilience efforts and actions despite of the multi-risks from internal and external aspects and do remain apply the copings either in the short-medium term or in the medium-long term. The assessment of social and cultural copings for flood disaster is conceptualized in the qualitative sub-questions of this study, they are (1) to what extent is the flood hazard mapping and its flood characteristics assessment could be understood by local communities in dealing with their ownership and implementation of social and cultural copings ?; (2) What and how could social and cultural copings be applied and enhanced by the quality of the daily adjustment process encountered and dealt by the community with the flood situation that occurs? (3) Could the application of this CMS strengthen the social and cultural copings of the local community in facing flood disaster in a long process or period of time?, and (4) Which type of copings could be considered as the main invaluable local copings of community in this discourse of sustainability?. These four sub-questions in this study use the risk perception of key local stakeholders in three flood-affected villages (Lasaen, Umatoos, and Fafoe) in order to understand and discuss the forms and patterns of diversity of collective action of copings in the specific concepts of risk management and resilience. This CMS is presented in this following Figure 2 CMS (See also for a more detail this explanation under the next sections 4.4, "CMS Based Local Participatory Flood Hazard Mapping's Assessment and Coping: Reflective and Discourse Analysis for Sustainability" and its sub-sections). 


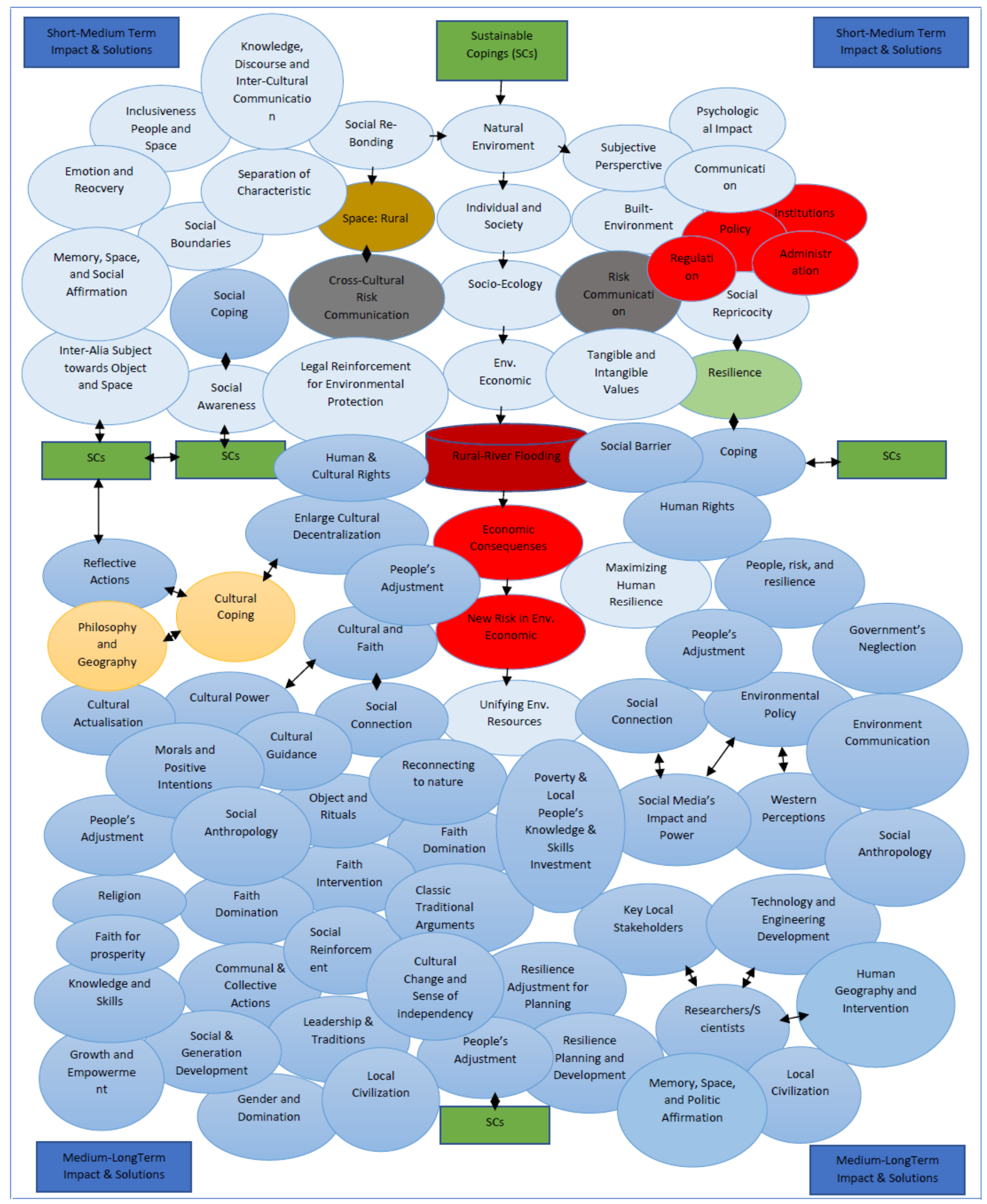

Figure 2. CMS

Source: Author's own model 


\section{Results and Discussion}

\subsection{Flood Frequency and Flood Distribution or Flood Extent based on the Interview and FGDs}

The flood has began since 1939, and lasted every twenty years thereafter, until 1999-2000 (post-political disaster; Timor Leste and Indonesian civic war were occurred in this time). From 2000 flood was occurred every year until 2012 (See also Table 1, "Flood hazard mapping assessment (flood characteristics) and social and cultural copings" in page 16-19).

\subsubsection{Flood Frequency}

Flood frequency is defined as the return period of its occurrence. The return period is the time period over which it is likely that a particular magnitude flood will occur (Frazer, 2010). According to FGDs and interview of 60 affected people of flood disaster in Lasaen village, Umatoos village, and Fafoe village, river flooding has began since 1939, 1959, 1975, 1979, 2000 until 2012. (This research was conducted in July 2012 through August 2012; one-month fieldwork).

\subsubsection{Flood Distribution or Flood Extent}

Based on interview with 60 households and the FGDs' data with key local stakeholders, it was informed that all of sites at three villages i.e., Lasaen, Umatoos and Fafoe are inundated by river flooding though with different site's elevation. The flood distribution or flood extent is distributed over three villages which is shown in this following Figure 3, "Flood Distribution or Flood Extent Map".

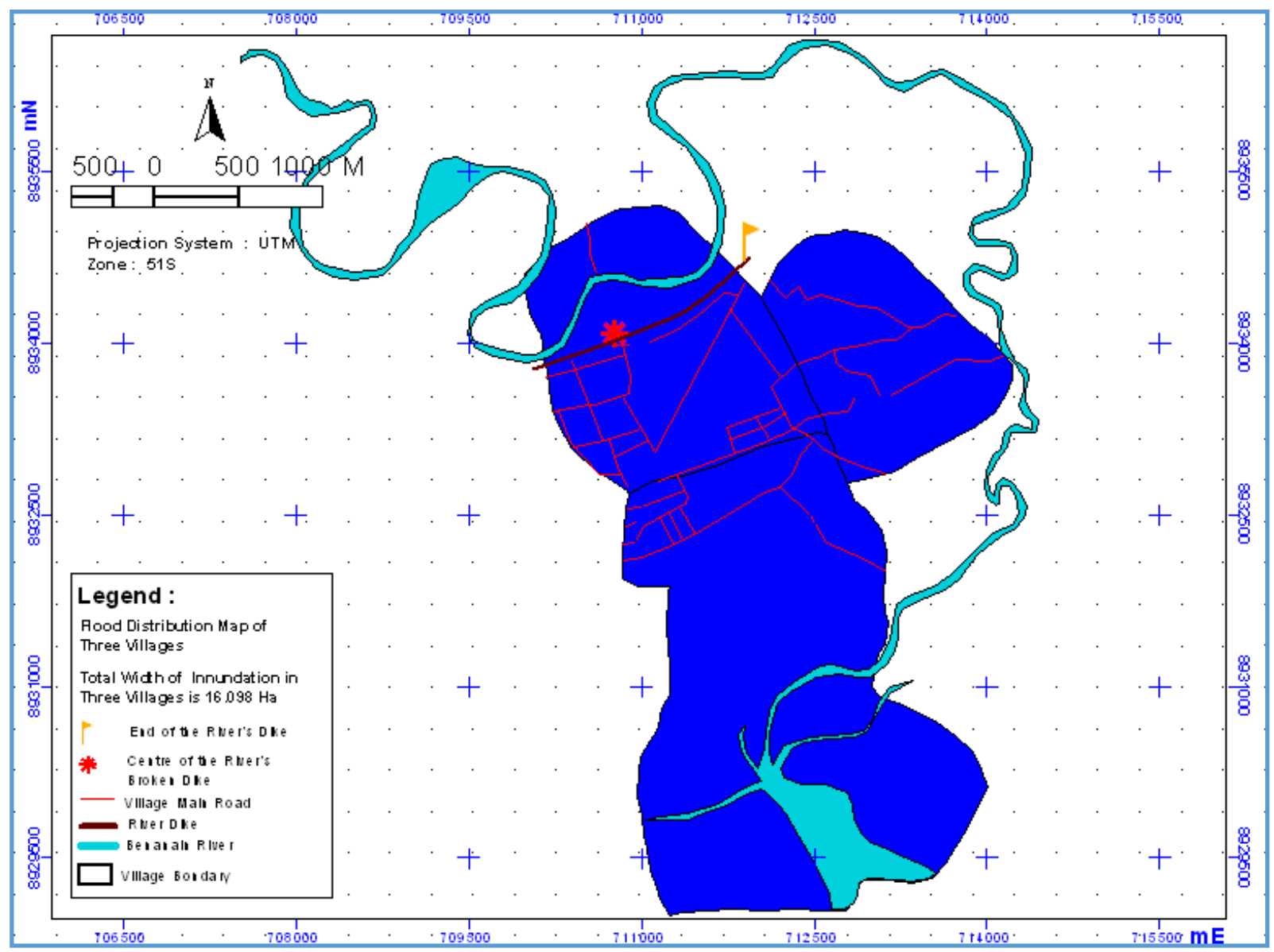

Figure 3. Flood distribution or flood extent map

Source: Author's own map

\subsection{Flood Duration based on the Interview and FGDs at Lasaen, Umatoos and Fafoe villages}

Flood risk perception on flood disaster situations which was assessed from the flood characteristics' point of view, was obtained through the interviews and FGDs, is therefore described in this section. Basically, the three villages 
affected by the river flooding i.e., Lasaen, Umatoos and Fafoe have the same geographic and topographic characteristics (the flattest areas or villages of the other thirteen villages of Belu Regency i.e., Besikama, Lofoun, Raimataus, Rabasa, Rabasahain, Rabasahaerain, Motaulun, Motaain, Umaloor, Maktihan, Naas, Oanmane, and Sikun). These three villages are nearby the Abudenok estuary which is located at Umatoos village, as we can see in Figure 3 above, the estuary is placed at the boundary between the Timor Ocean and the Benanain riverbank, and are at a point of incontinence due to damage and cessation of embankment and drainage (as a means of protecting the risk of flooding that will overflow through these three villages). Moreover, with the unavailability of the Indonesian local Government policies from local level (Belu Regency), regional level (Western Timor Island of the East Nusa Tenggara Province) and national level (central Government of Indonesia) seemed to let this situation get worse without the controlling and monitoring systems of anticipation, preparedness, mitigations and recovery of the flood hazards as well as the protection measures and their effectiveness in terms of infrastructure or physical resilience (broken embankment and drainage) and social and cultural copings. The problem of dysfunctional of embankment and drainage at these most affected villages causing the speed overflow of river flooding from the Benanain river in each seasonal flooding (raining period) every year, has been spreading its water over and across these three villages and leaving them at long duration of water inundations and making each households had to cope with, recover from, and utilizing or strengthening more their social and cultural coping systems from the short term, medium term and long term. The assessment of social and cultural copings in response to flood characteristics in this study is on the focus of this section's discussion.

\subsubsection{Flood Duration based on Interview}

Duration of flood inundation that impacted the household's house in Lasaen and Umatoos villages are similar, starting from ranges days of 0-7 days, 8-14 days and $>15$ days. Whereas flood duration in Fafoe village is very long with a minimum duration of 1 week and 1 month maximum. Duration of flood inundation in this village is longer than the other two villages (Lasaen and Umatoos) due to lack of drainage system that located at these three villages where the vulnerable point of river flooding in the south to western part of these three villages is Fafoe village. Thus, when the rainy season comes while there was no good drainage system that these three villages have, leaving the Fafoe village with more extra-social and cultural copings to manage the river flooding. The access of water in Fafoe village was leaking and cutting off where its water of flood first entered this village. Besides, moreover, it was also caused by the flow of the Benanain river that crosses Fafoe village which is in the western part of these three villages is then highly vulnerable to river flooding. In addition, the collapse of the embankment in Umamota subvillage of Lasaen village and the other village (Sikun village) makes the accessibility between Lasaen and Fafoe villages were not working properly (See the red point at the center of the broken embankment and an orange flag as shown in the Figure 3 above which are known as the symbols of the broken embankment in Lasaen and Sikun villages). This case is resulted both these villages was flooded. Nonetheless, Fafoe village remains in a poorer condition than Lasaen and Umatoos villages. The duration of flood inundation that disrupted the household's house in Lasaen, Umatoos and Fafoe villages can be seen in Figure 4, Figure 5 and Figure 6 below. 


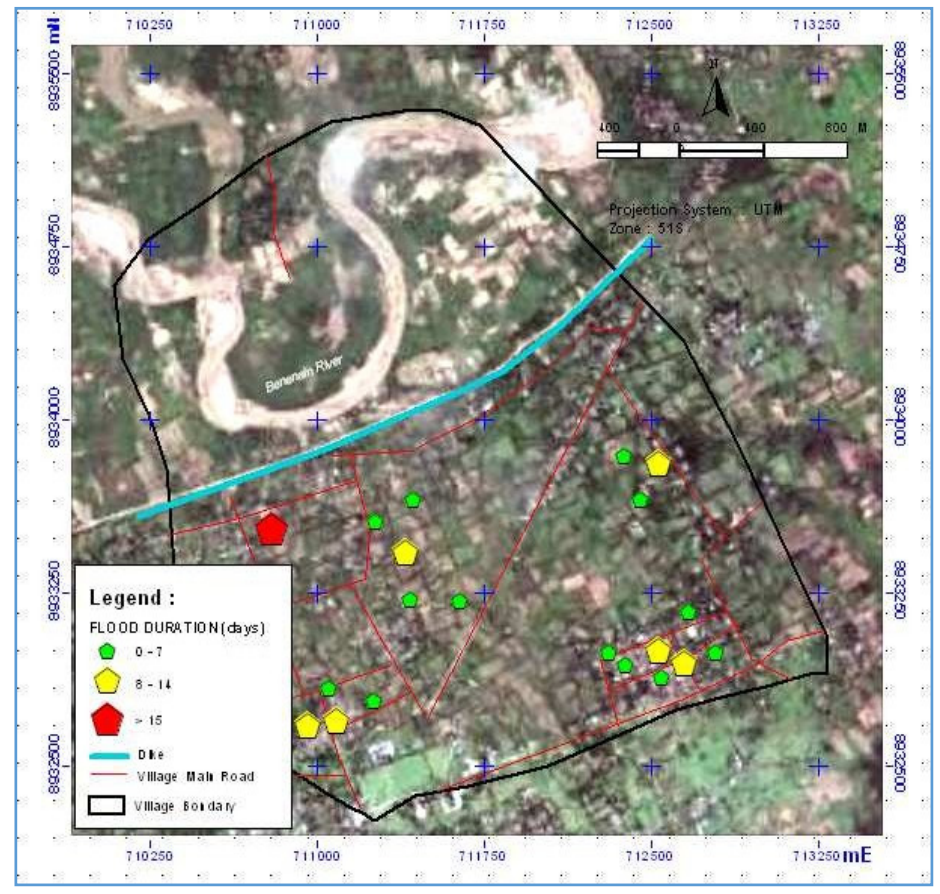

Figure 4. Flood Duration based on Interview in Lasaen village

Source: Author's own map (2012)

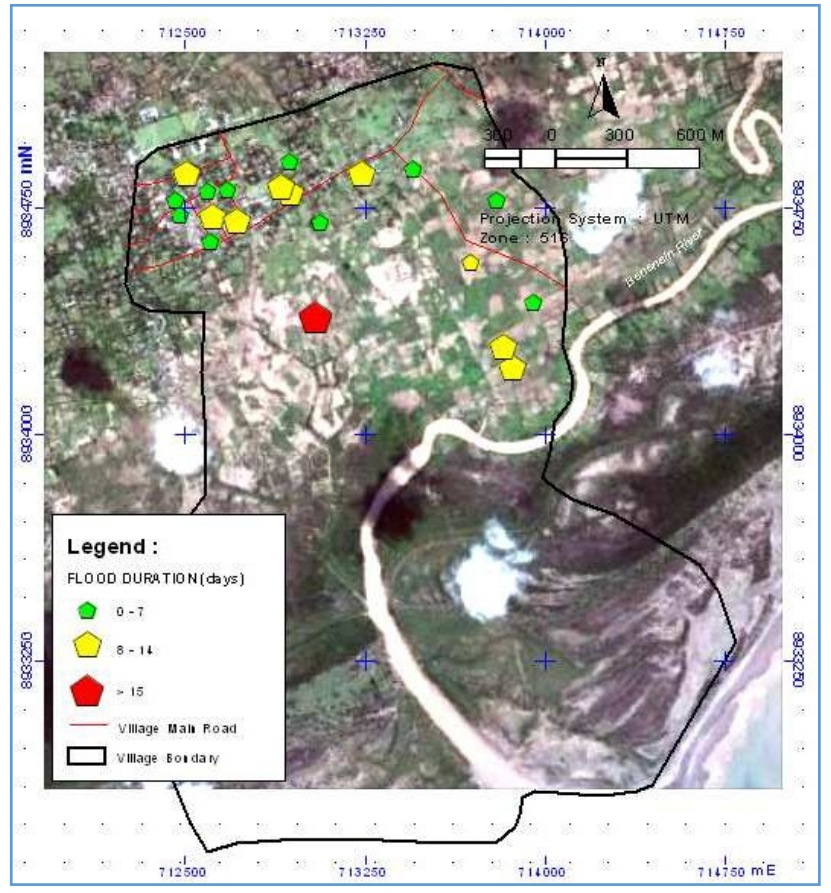

Figure 5. Flood Duration based on Interview in Umatoos village Source: Author's own map (2012)

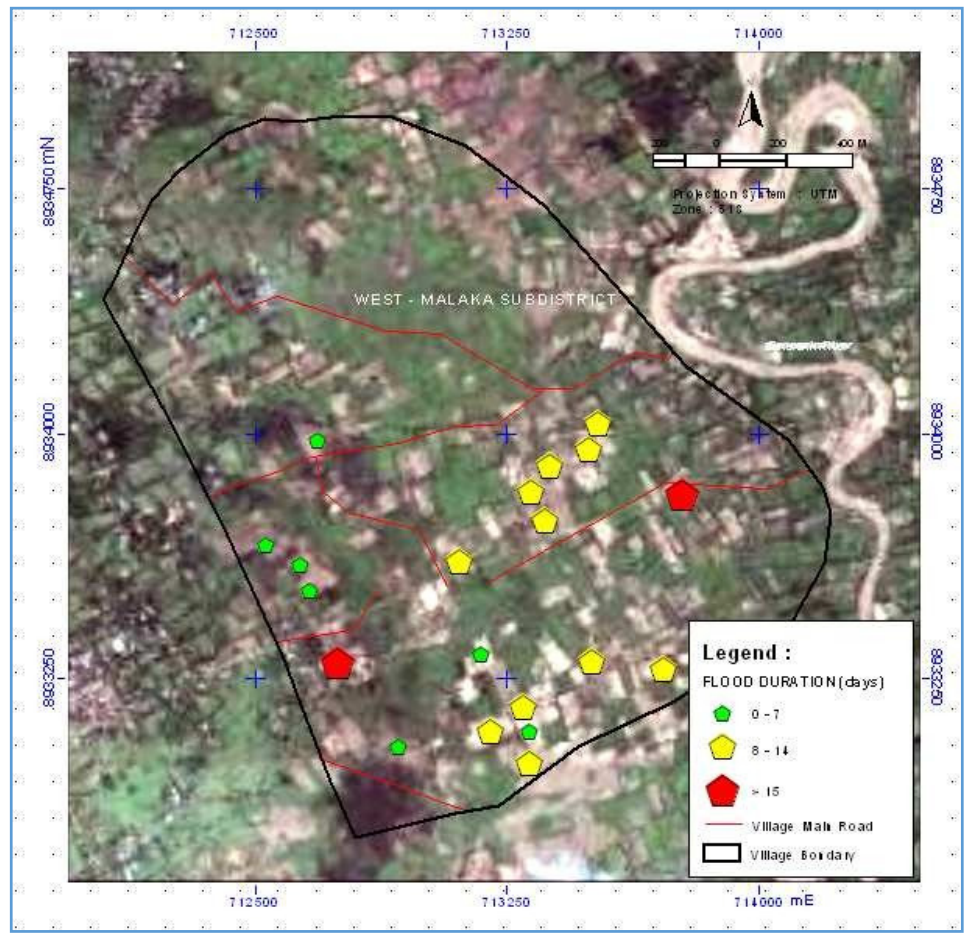

Figure 6. Flood Duration based on Interview in Fafoe village

Source: Author's own map (2012)

\subsubsection{Flood Duration based on FGDs}

Flood duration in Lasaen Village has similar level range days with Fafoe Village which started from 0-7 days, 714 days and 14-21 days. While, flood duration on Umatoos Village is started from 7-14 days and 14-21 days. Precisely, the community who stayed nearby the collapsed embankment got more flood hazard than those who 
stayed in southern and western part of the collapsed embankment. Community who determined and gave rank classes of flood duration. They have perception that the length of flood duration is disrupting their daily activities in term of socio-economy. Duration of Flood Inundation that affected the Respondent's House in Lasaen village, Umatoos village and Fafoe village can be seen in Figures 7, Figure 8 and Figure 9 below.

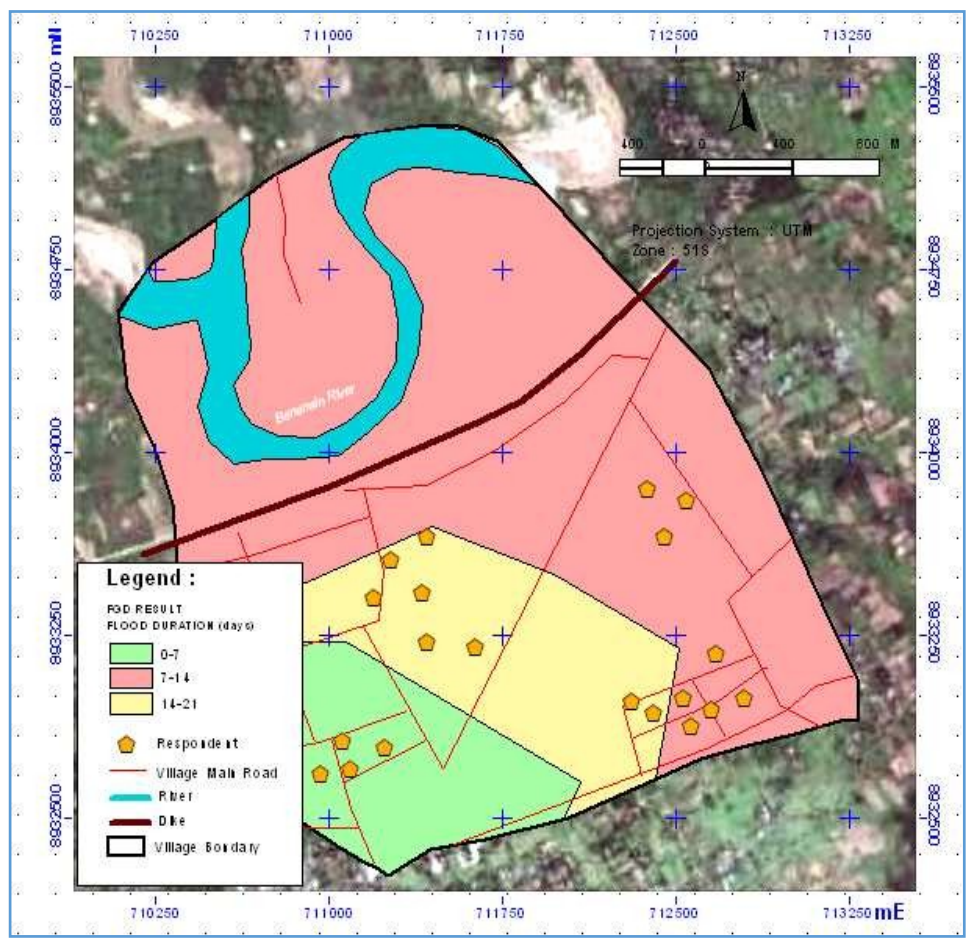

Figure 7. Flood Duration based on FGDs in Lasaen village

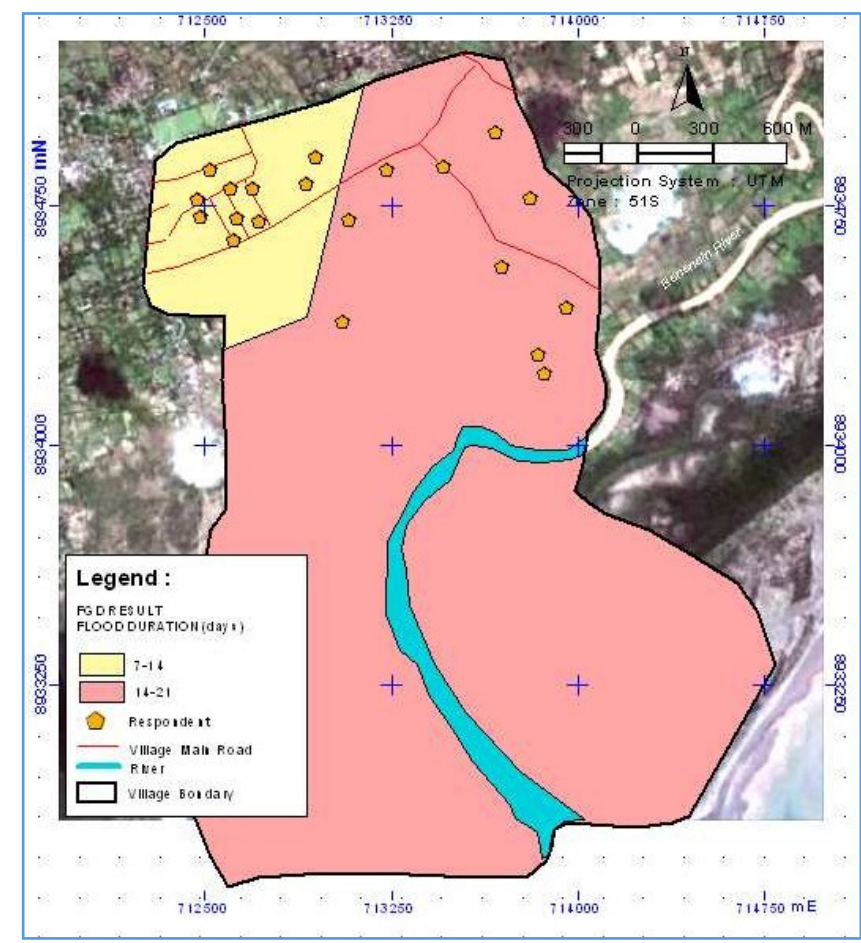

Figure 8. Flood Duration based on FGDs in Umatoos village Source: Author's own map

Source: Author's own map

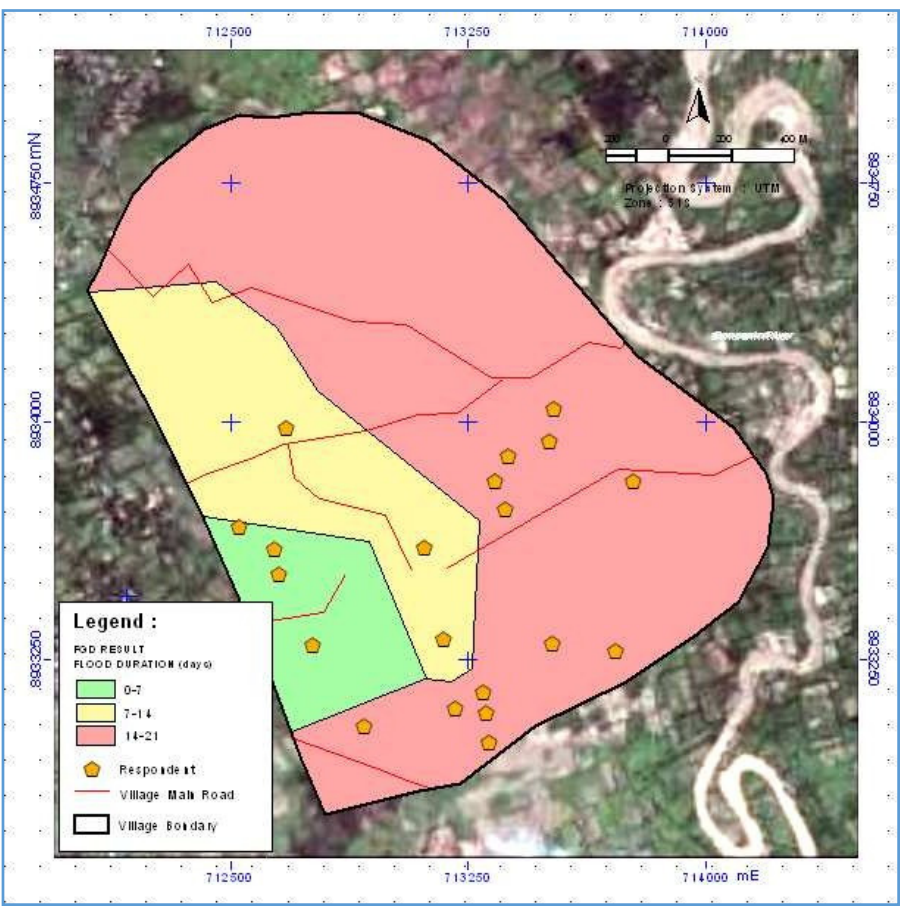

Figure 9. Flood Duration based on FGDs in Fafoe village

Source: Author's own map 


\subsection{Flood Depth based on Interview}

Flood depth in three Lasaen, Umatoos, and Fafoe villages has been susceptible for each 60 households. The determination of the sustainability and effectiveness of farming (agriculture activities in social and cultural copings) was also determined by the depth of water inundation due to river flooding. Flood depth that has affected each household's house over three villages have the zone level, starting from the lowest depth of 0-50 centimeter (cm) until deepest of 251-300 cm. The different zone level of flood depth that was indicated by the local strategy applied by community in reconstructing their house's foundation and terrace's building. The flood depth points were measured based on the ground floor as reference and then that point was added with the height of foundation for each building of house (Zein, 2010). Dewi (2007) stated out that the level of flood depth was measured inside the house with reference to the plinth or ground floor. Each household or family in Lasaen, Umatoos, and Fafoe villages built their houses with the poles and building materials that are resistant or protective against the flood hazards. The characteristic of each household's house is in the form of a house on stilts with a leaf roof, a wooden house building with a floor foundation and a front porch of the house's height was $60 \mathrm{~cm}$. Meanwhile, houses building which are made of cement, zinc roofs, and cement or ceramic floors have a floor and a front terrace's height is between $60-85 \mathrm{~cm}$. Different maximum flood height perceived within the house varies according to the height of the building above sea level (elevation) and flood proofing measures like raised entrances, raised foundation of the house, etc (Febrianty 2010). The flood depth maps of each 60 households who were affected by river flooding in Lasaen, Umatoos and Fafoe villages can be seen in Figure 10, Figure 11 and Figure 12 below.

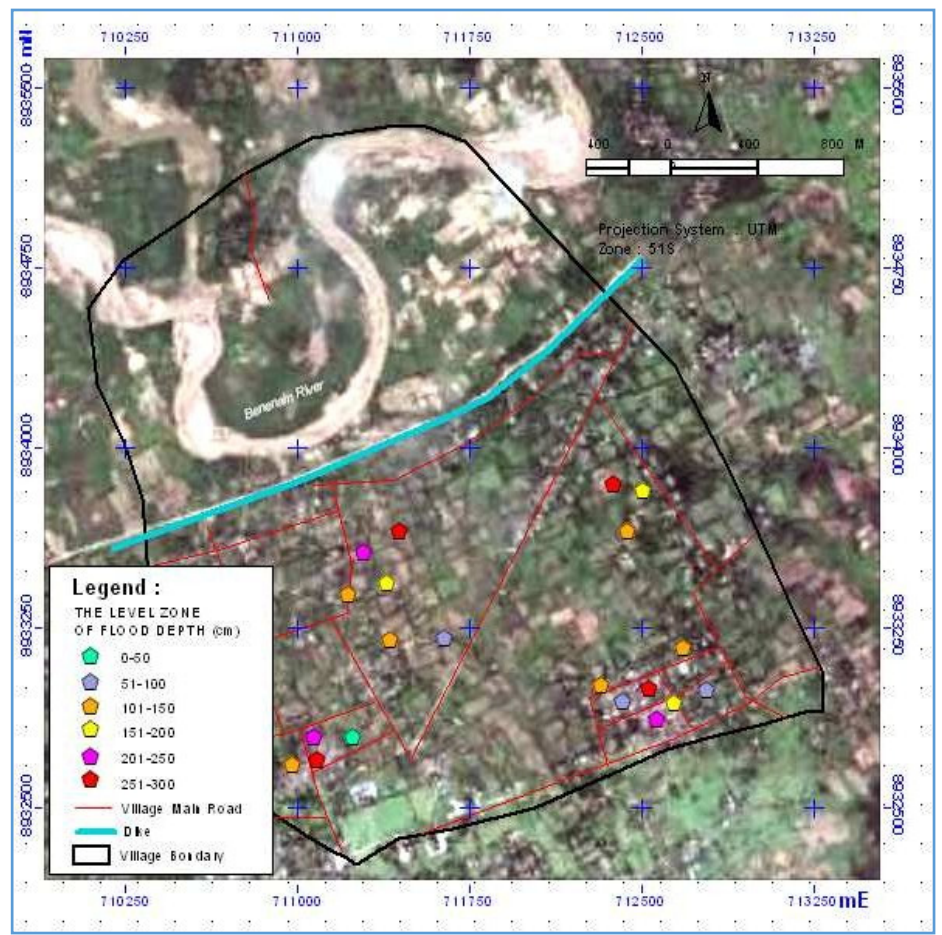

Figure 10. Flood Depth based on Interview in Lasaen village Source: Author's own map

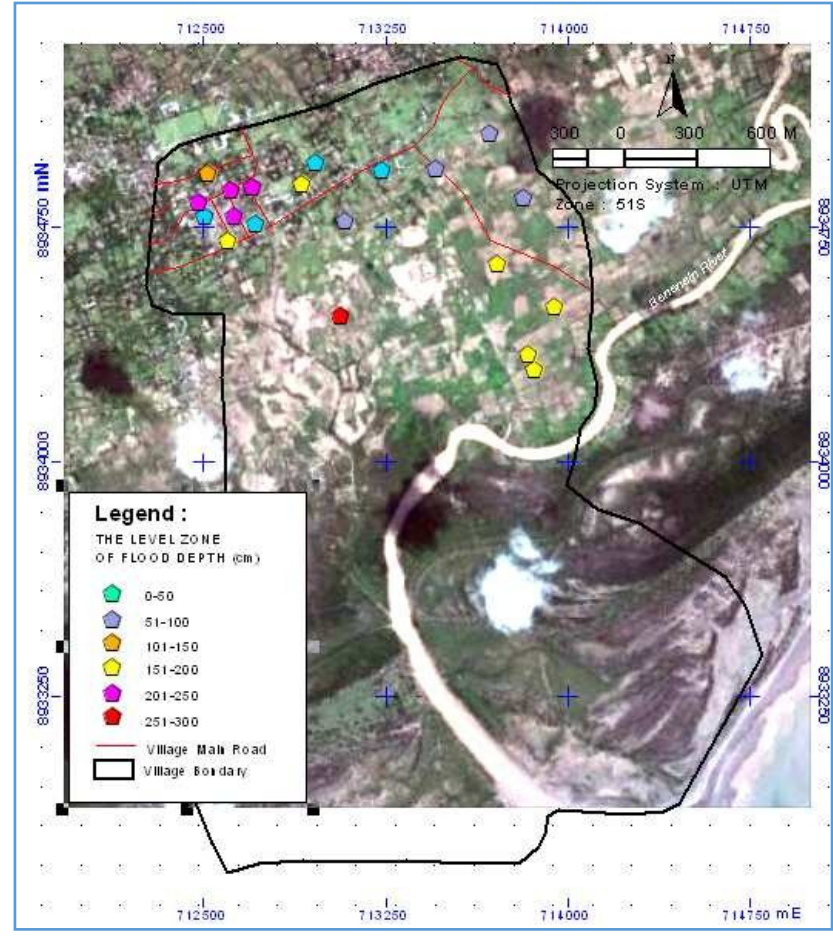

Figure 11. Flood Depth based on Interview in Umatoos village Source: Author's own map 


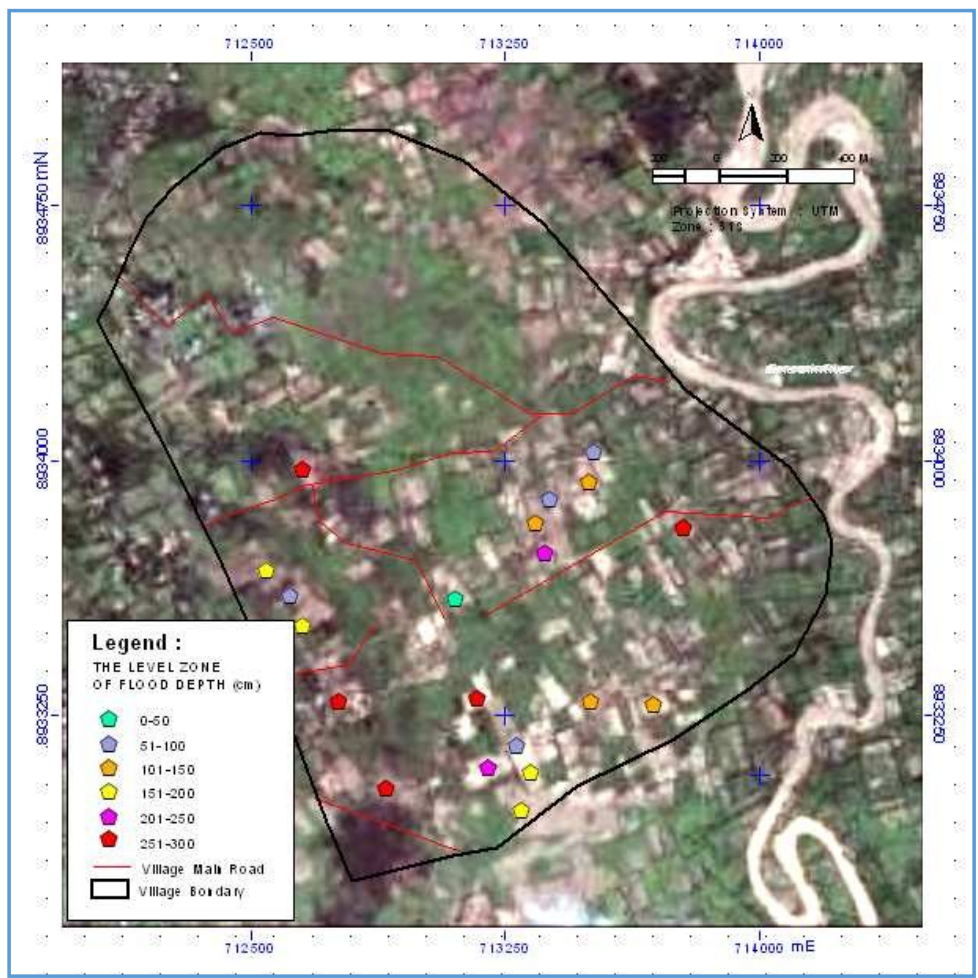

Figure 12. Flood Depth based on Interviews in Fafoe village

Source: Author's own Map

4.4 CMS Based Local Participatory Flood Hazard Mapping's Assessment and Coping: Reflective and Discourse Analysis for Sustainability

As presented in Figure 2. CMS of Section 3.5, in the assessment and discussion of copings in a specific way, it thus can be described in these results or outcomes through various and cross-disciplines where the terms were expressed from the model, and that there are some subjective and objective specific series of assessment which are then considerably and properly examined on this study for each of this copings analysis. Each of four subquestions of this study (see Figure 2) is discussed on this section by providing its schematic integration and a concise assessment.

$\Longrightarrow$ The four sub-questions of this research are:

Question 1 (Q1): to what extent is the flood hazard mapping assessment (flood characteristics) could be understood by local communities in dealing with their ownership and implementation of social and cultural copings?

This research's definition of coping, social and cultural copings is presented:

a) Coping is defined as human efforts to interpret the resilient processes or actions that are carried out by them are expected to be in harmony way, balance and/or integrated with the adjustment of oneself psychologically and to the flood disaster' problems that threaten life and the environment.

b) Social coping is defined as a coping's process or formidable collective action within the social environment unit in a local community structure, where togetherness and mutual assistance are expected to be able to bind social values, to connect and accept social assistance through both individual and group mechanisms as to reach a wide network from external society.

c) Cultural coping is defined as a coping's ability of each individual and group of a certain community along with discourses, historical values, civilization, and cultural capabilities and beliefs that live, grow and nurture, and process with the dynamics of social or humanitarian problems, and changes or natural hazards including flood problems; it is however not binding to the social structure of the outside community (local inclusiveness).

Q2: What and how could social and cultural copings be applied and enhanced by the quality of the daily adjustment's processes were encountered and dealt by the community with the flood situation that occurs?

This research's definition of social and cultural copings' enhancements and adjustment for flood disaster is 
presented:

a) Social coping enhancement deals with a continuously and gradually of a coping process, is strengthened by local community's collective action that is inter and cross-understanding or locally based knowledge, to reach every mechanism and solutions from each individual and group in a long-term period (sustainable).

b) Cultural coping enhancement deals with the coping ability of each individual and group from a particular community that has effectively implemented or transformed all discourses, historical values, civilization values, cultural wisdom and compliance or obedience of cultural rules, and cultural beliefs that live and maintained in addressing the dynamics of detailed and complexity social or humanitarian problems, and ready to accept (adjust) to an ecosystem's change or natural hazard i.e., flood that threatens their survival and ecosystem; without eliminating, or reducing and ignoring the essence and characteristics of the local culture as a reflection of strength or resilience itself.

c) Adjustment is the coping process, the learning process, or the ability of individuals and communities that are patterned from the mechanisms of social and cultural forces; and its every single of implemented mechanism (social and culture) was truly understood, accommodated, regulated, controlled, and sustained by communities in overcoming the flood problem.

Q3: Could the application of this CMS strengthen the social and cultural copings of the local community in facing flood disaster in a long process or period of time?

(Qualitative descriptive analysis was utilized in revealing the answer of this third sub-question. Analysis on the long-term concept of both social and cultural copings using CMS is about the performance of its model could be of significant helpful the local community in understanding their own copings, which last in the short-medium period or medium-long period).

Q4: Which type of copings could be considered as the main invaluable local copings of community in this discourse of sustainability?

This research's definition of discourse sustainability and invaluable coping are presented:

a). Discourse sustainability in this study's analysis is related to the cultural coping enhancement in which this definition is part of, but focuses in particular on the analysis of the ability of each individual and group to effectively implement or transform all discourse, historical values, civilization values, cultural wisdom and compliance or obedience, cultural rules, and cultural beliefs as the basis for local people's resilience to adapt to changes in ecosystems or natural hazards such as floods.

b). Invaluable coping is a combination of definitions between or refers to cultural coping and cultural coping enhancement which are on this analysis hereby so called as an environmental unit of coping-transformation (social-cultural copings) of each collective action and the cultural values and capabilities, and of cultural wisdom are contained and sustained in the local community resilience system to response to flood hazard.

$\longrightarrow \quad$ The discussion and assessment in answering the questions:

Answer 1 (A1): The local community's understanding about their social and cultural copings that they had and implemented in dealing with flood problems (flood hazard maps were mapped by them). This discussion and assessment are presented in this following Table 1, "Flood hazard mapping assessment (flood characteristics) and social and cultural copings".

Table 1. Flood hazard mapping assessment (flood characteristics) and social and cultural copings

Local community's understanding (risk perception) about their own social and cultural copings in response to the current flood hazard mapping

assessment that they mapped using pGIS through FGDs and the result of Interviews

\begin{tabular}{|c|c|c|c|c|c|c|}
\hline \multirow{3}{*}{$\begin{array}{l}\text { Flood } \\
\text { Mapping }\end{array}$} & \multicolumn{3}{|c|}{ Social coping } & \multicolumn{3}{|c|}{ Cultural coping } \\
\hline & Individual & Social rebound & Social connection \& & Actualisation & Leadership & intervention \\
\hline & justice-Social & $\&$ affirmation & partnership: collective & of the cultural & female & (religion \\
\hline Assessment (Flood & networking & & stimuli actions and & power from & chief and key & resilience/adjustment) \\
\hline Characteristics) & & & emotions & every & local & \\
\hline
\end{tabular}




\begin{tabular}{|c|c|c|c|c|c|c|}
\hline & & & $\begin{array}{l}\text { (psychological } \\
\text { resilience/adjustment) }\end{array}$ & $\begin{array}{l}\text { individual- } \\
\text { social's belief, } \\
\text { change \& } \\
\text { development } \\
\text { (behavior } \\
\text { change; habits } \\
\text { nurtured as } \\
\text { actions and } \\
\text { copings) }\end{array}$ & $\begin{array}{l}\text { stakeholders) \& } \\
\text { traditions for } \\
\text { moral values } \\
\text { (intangible) }\end{array}$ & \\
\hline $\begin{array}{l}\text { Flood } \\
\text { Frequency/period } \\
\text { Each twenty years } \\
\text { \& each one year: } \\
\text { 1939, 1959, 1979, } \\
\text { 1999-2000, and } \\
\text { from 2001-2012 } \\
\text { flood occurred } \\
\text { every year }\end{array}$ & $\begin{array}{l}\text { During this } \\
\text { period of } \\
\text { flood, } \\
\text { individual and } \\
\text { households } \\
\text { has } \\
\text { his/her/their } \\
\text { own } \\
\text { regulative } \\
\text { efforts to be } \\
\text { involved in } \\
\text { local social } \\
\text { network } \\
\text { without } \\
\text { Institution' } \\
\text { interventions }\end{array}$ & $\begin{array}{l}\text { The case of the } \\
\text { 1999-2000's } \\
\text { flood period } \\
\text { presented an } \\
\text { effective initial } \\
\text { social rebound } \\
\text { \& affirmation } \\
\text { during the } \\
\text { civic war } 1999 \\
\text { between East } \\
\text { Timor and } \\
\text { Indonesia; } \\
\text { most relocated } \\
\text { east Timorese } \\
\text { who were } \\
\text { deciding in the } \\
\text { referendum } \\
\text { vote as pro- } \\
\text { integration } \\
\text { (Indonesia) } \\
\text { were also } \\
\text { victims of river } \\
\text { flooding in the } \\
\text { research site }\end{array}$ & $\begin{array}{l}\text { East Timorese people } \\
\text { in Belu were } \\
\text { disconnected to local } \\
\text { community in Belu in } \\
\text { the building of social } \\
\text { partnership due to lack } \\
\text { of adjustment to } \\
\text { manage floods; each } \\
\text { individual (locale) } \\
\text { awareness has to be } \\
\text { built in strengthening } \\
\text { their actions of coping } \\
\text { through effective } \\
\text { support of each } \\
\text { member of community } \\
\text { in releasing emotions } \\
\text { and perceptions }\end{array}$ & $\begin{array}{l}\text { Each flood } \\
\text { season, rapid } \\
\text { actualization } \\
\text { of the cultural } \\
\text { power of each } \\
\text { individual to } \\
\text { implement } \\
\text { social's belief, } \\
\text { guided by } \\
\text { female tribal } \\
\text { chief and key } \\
\text { local } \\
\text { stakeholders } \\
\text { was an } \\
\text { evidence of } \\
\text { local cultural } \\
\text { coping was, } \\
\text { while it was } \\
\text { still also } \\
\text { leaving } \\
\text { uncertainty of } \\
\text { what kind of } \\
\text { cultural trust } \\
\text { that enables to } \\
\text { nurture their } \\
\text { from poundaries } \\
\text { actions for the } \\
\text { long-term } \\
\text { development. } \\
\text { This was due } \\
\text { to titical }\end{array}$ & $\begin{array}{l}\text { Effective role } \\
\text { was taken by } \\
\text { female tribal } \\
\text { chief and key } \\
\text { local } \\
\text { stakeholders in } \\
\text { leading and } \\
\text { guiding the local } \\
\text { community in } \\
\text { each flood } \\
\text { season; fidelity } \\
\text { of practicing } \\
\text { local traditions } \\
\text { (rituals) and } \\
\text { beliefs to } \\
\text { enhance moral } \\
\text { values among } \\
\text { member of } \\
\text { community }\end{array}$ & $\begin{array}{l}\text { Collaboration of } \\
\text { encouraging local } \\
\text { community's cultural } \\
\text { copings when flood } \\
\text { strikes their area, } \\
\text { between local leaders } \\
\text { and religious leaders } \\
\text { (Christian-Catholic) } \\
\text { were quite cooperative }\end{array}$ \\
\hline
\end{tabular}




\begin{tabular}{|c|c|c|c|c|c|c|}
\hline & & & & $\begin{array}{l}\text { intervene the } \\
\text { flood and } \\
\text { cultural } \\
\text { resilience } \\
\text { problems }\end{array}$ & & \\
\hline $\begin{array}{l}\text { Flood } \\
\text { Distribution/extent } \\
\text { Water inundation } \\
\text { during and in the } \\
\text { ex-post of river } \\
\text { flooding }\end{array}$ & 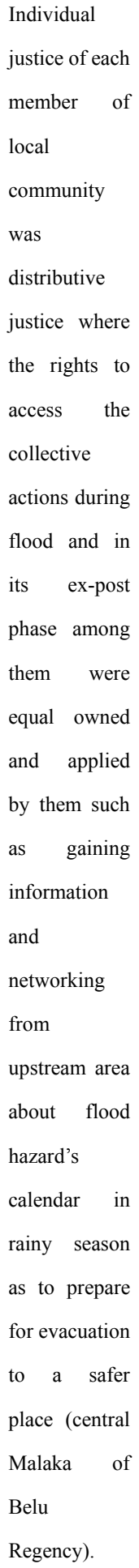 & $\begin{array}{l}\text { Social re- } \\
\text { bounding and } \\
\text { affirmation } \\
\text { were } \\
\text { established by } \\
\text { local } \\
\text { community } \\
\text { after flood } \\
\text { occurred. } \\
\text { Recovery } \\
\text { system so } \\
\text { called } \\
\text { hakawak (Belu } \\
\text { Tetun } \\
\text { language) or } \\
\text { mutual } \\
\text { assistance was } \\
\text { carried out by } \\
\text { local } \\
\text { community in } \\
\text { cleaning the } \\
\text { mud of flood. } \\
\text { Neighborhood } \\
\text { help } \\
\text { working } \\
\text { effectively by } \\
\text { utilizing } \\
\text { local/domestic } \\
\text { equipments to } \\
\text { clean the mud. }\end{array}$ & 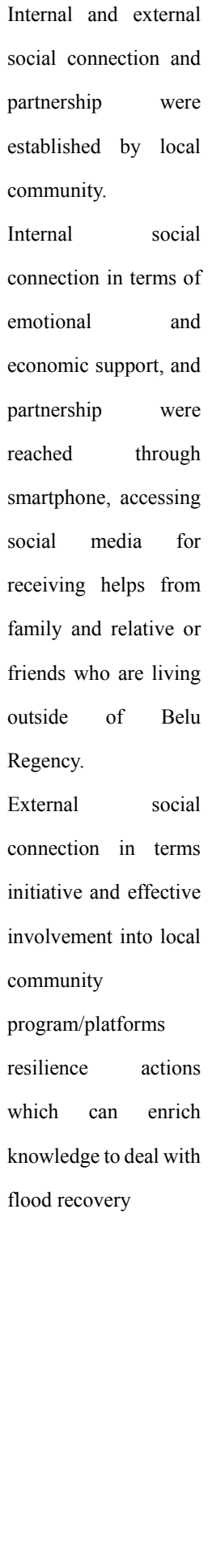 & $\begin{array}{l}\text { Maintain } \\
\text { intrinsic value } \\
\text { in cultural } \\
\text { capital i.e., } \\
\text { ritual or } \\
\text { worship to the } \\
\text { ancestor, done } \\
\text { by female } \\
\text { tribal chief. } \\
\text { This was } \\
\text { practiced } \\
\text { during and ex- } \\
\text { post flood } \\
\text { disaster. } \\
\text { Cultural } \\
\text { power of } \\
\text { community is } \\
\text { strengthened } \\
\text { by their } \\
\text { invisible } \\
\text { power from } \\
\begin{array}{l}\text { Mighty that } \\
\text { they believed, } \\
\text { can help } \\
\text { protect them }\end{array}\end{array}$ & $\begin{array}{l}\text { Key local } \\
\text { stakeholders } \\
\text { were often with } \\
\text { female tribal } \\
\text { chief applied the } \\
\text { ritual or worship }\end{array}$ & $\begin{array}{l}\text { Both key local } \\
\text { stakeholders and } \\
\text { female tribal chief } \\
\text { were cooperated with } \\
\text { the religious leaders to } \\
\text { engage with social } \\
\text { security } \\
\text { protections of the local } \\
\text { people. The venue is } \\
\text { Church and/or local } \\
\text { health center as the } \\
\text { place where the risk } \\
\text { information, alarming } \\
\text { system before flood } \\
\text { occurs, and recovery } \\
\text { after flood occurred } \\
\text { were provided by the } \\
\text { local religious leaders, } \\
\text { health personnel staffs } \\
\text { (volunteer). Disaster } \\
\text { volunteer group was } \\
\text { initiated by key local } \\
\text { stakeholders was also } \\
\text { involved into these } \\
\text { social-cultural } \\
\text { collaborations } \\
\text { enhance their social } \\
\text { and cultural copings. }\end{array}$ \\
\hline
\end{tabular}




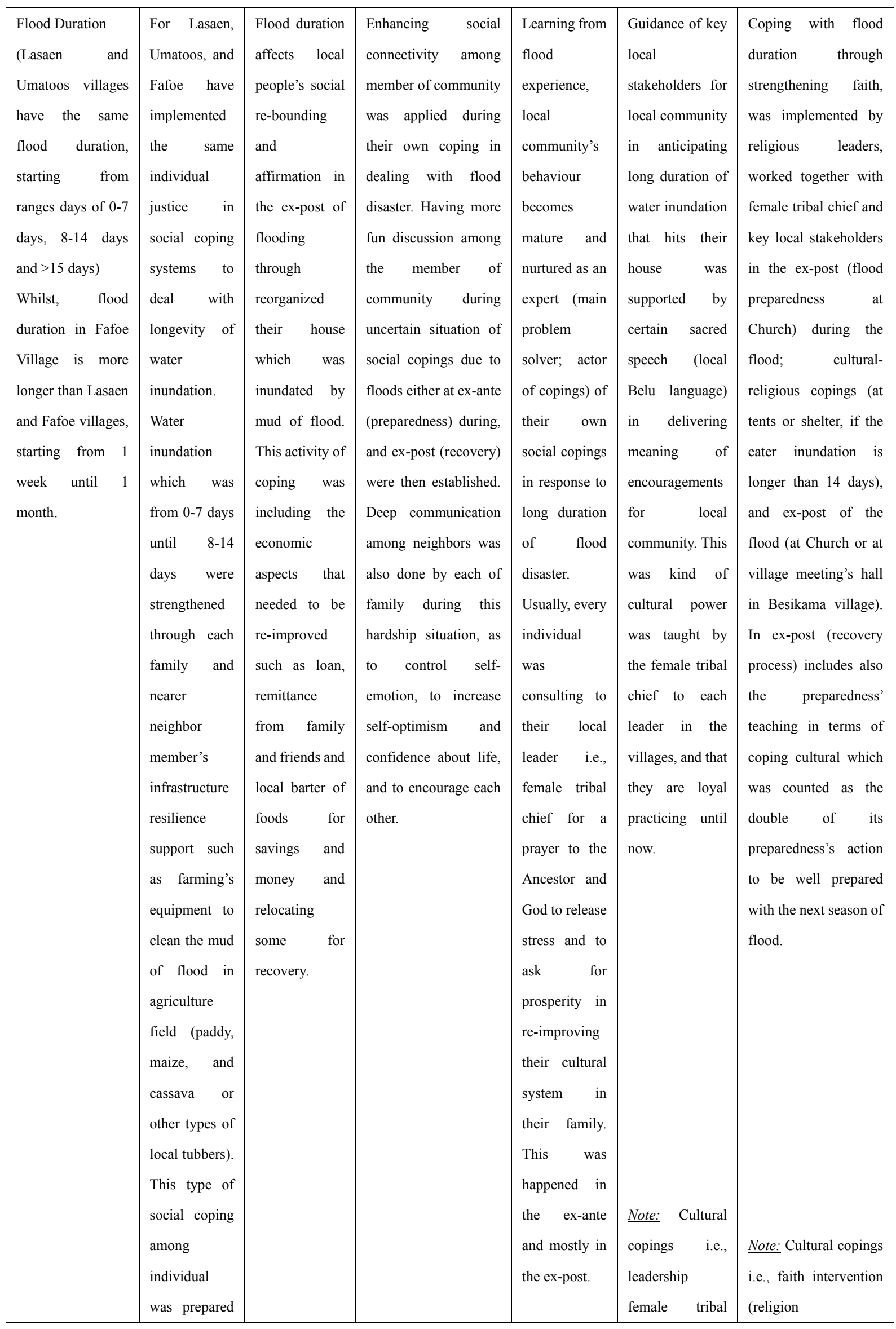




\begin{tabular}{|c|c|c|c|c|c|c|}
\hline & $\begin{array}{l}\text { in the ex-ante } \\
\text { (before flood } \\
\text { occurs) } \\
\text { Whilst, if } \\
\text { water } \\
\text { inundation } \\
\text { hits their } \\
\text { villages for } \\
\text { more than } 14 \\
\text { days, the } \\
\text { households } \\
\text { have to be } \\
\text { evacuated to a } \\
\text { shelter, } \\
\text { provided, and } \\
\text { organized by } \\
\text { key local } \\
\text { stakeholders } \\
\text { from each } \\
\text { village's } \\
\text { disaster group } \\
\text { volunteer }\end{array}$ & & & $\begin{array}{l}\text { Note: Cultural } \\
\text { copings i.e., } \\
\text { actualisation } \\
\text { of the cultural } \\
\text { power from } \\
\text { every } \\
\text { individual- } \\
\text { social's belief, } \\
\text { change \& } \\
\text { development } \\
\text { in response to } \\
\text { flood duration } \\
\text { and flood } \\
\text { depth based } \\
\text { on FGDs were } \\
\text { revealing the }\end{array}$ & $\begin{array}{l}\text { chief and key } \\
\text { local } \\
\text { stakeholders) \& } \\
\text { traditions for } \\
\text { moral values } \\
\text { (intangible) in } \\
\text { response to flood } \\
\text { duration and } \\
\text { flood depth } \\
\text { based on FGDs } \\
\text { were revealing } \\
\text { the same } \\
\text { discussion and } \\
\text { assessment }\end{array}$ & $\begin{array}{l}\text { resilience/adjustment) } \\
\text { in response to flood } \\
\text { duration and flood } \\
\text { depth based on FGDs } \\
\text { were revealing the } \\
\text { same discussion and } \\
\text { assessment }\end{array}$ \\
\hline $\begin{array}{l}\text { Flood Depth } \\
\text { (Lowest depth of } \\
\text { water inundation } \\
\text { was } 0-50 \mathrm{~cm} \text { and } \\
\text { deepest of water } \\
\text { inundation was } \\
251-300 \mathrm{~cm} \text { were } \\
\text { experienced by } 60 \\
\text { households in } \\
\text { three villages) }\end{array}$ & $\begin{array}{l}\text { Flood depth } \\
\text { matters to } \\
\text { infrastructure } \\
\text { resilience } \\
\text { (house } \\
\text { construction) } \\
\text { of each } \\
\text { affected } \\
\text { household in } \\
\text { flood season. } \\
\text { For } \\
\text { household's } \\
\text { house that } \\
\text { was built by } \\
\text { the wooden } \\
\text { building } \\
\text { material, with } \\
\text { a leaf and soil- } \\
\text { floor; then } \\
\text { they must } \\
\text { increase the }\end{array}$ & $\begin{array}{l}\text { Flood depth in } \\
\text { social } \\
\text { rebounding } \\
\text { and } \\
\text { affirmation } \\
\text { among each } \\
\text { member of } \\
\text { local } \\
\text { community } \\
\text { was applied } \\
\text { thoroughly } \\
\text { mainly in the } \\
\text { ex-post } \\
\text { (recovery) by } \\
\text { sharing the } \\
\text { building } \\
\text { materials to } \\
\text { reconstruct } \\
\text { their house } \\
\text { such as } \\
\text { shovels, }\end{array}$ & $\begin{array}{l}\text { By considering their } \\
\text { social rebounding, the } \\
\text { social affirmation in } \\
\text { form of } \\
\text { communication was } \\
\text { assessed and perceived } \\
\text { by local community as } \\
\text { the way of } \\
\text { encouraging or } \\
\text { motivating (self- } \\
\text { esteem or self- } \\
\text { encouragement in } \\
\text { psychological } \\
\text { resilience in response } \\
\text { to or cope with the } \\
\text { consequences of flood } \\
\text { that threatened their } \\
\text { properties at house) } \\
\text { each other in the } \\
\text { society. They thought } \\
\text { them as human beings }\end{array}$ & $\begin{array}{l}\text { same } \\
\text { discussion } \\
\text { and } \\
\text { assessment }\end{array}$ & & \\
\hline
\end{tabular}




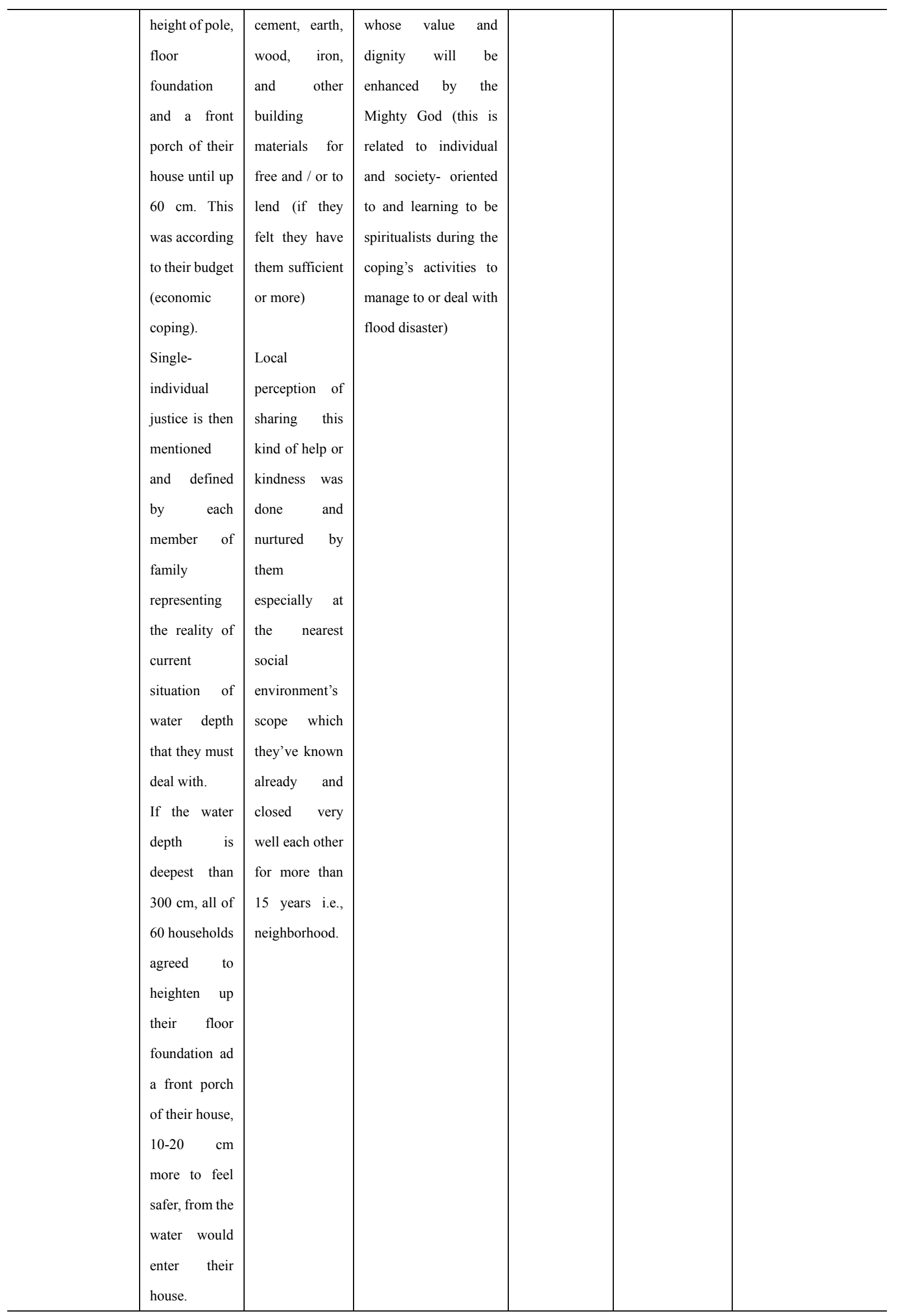




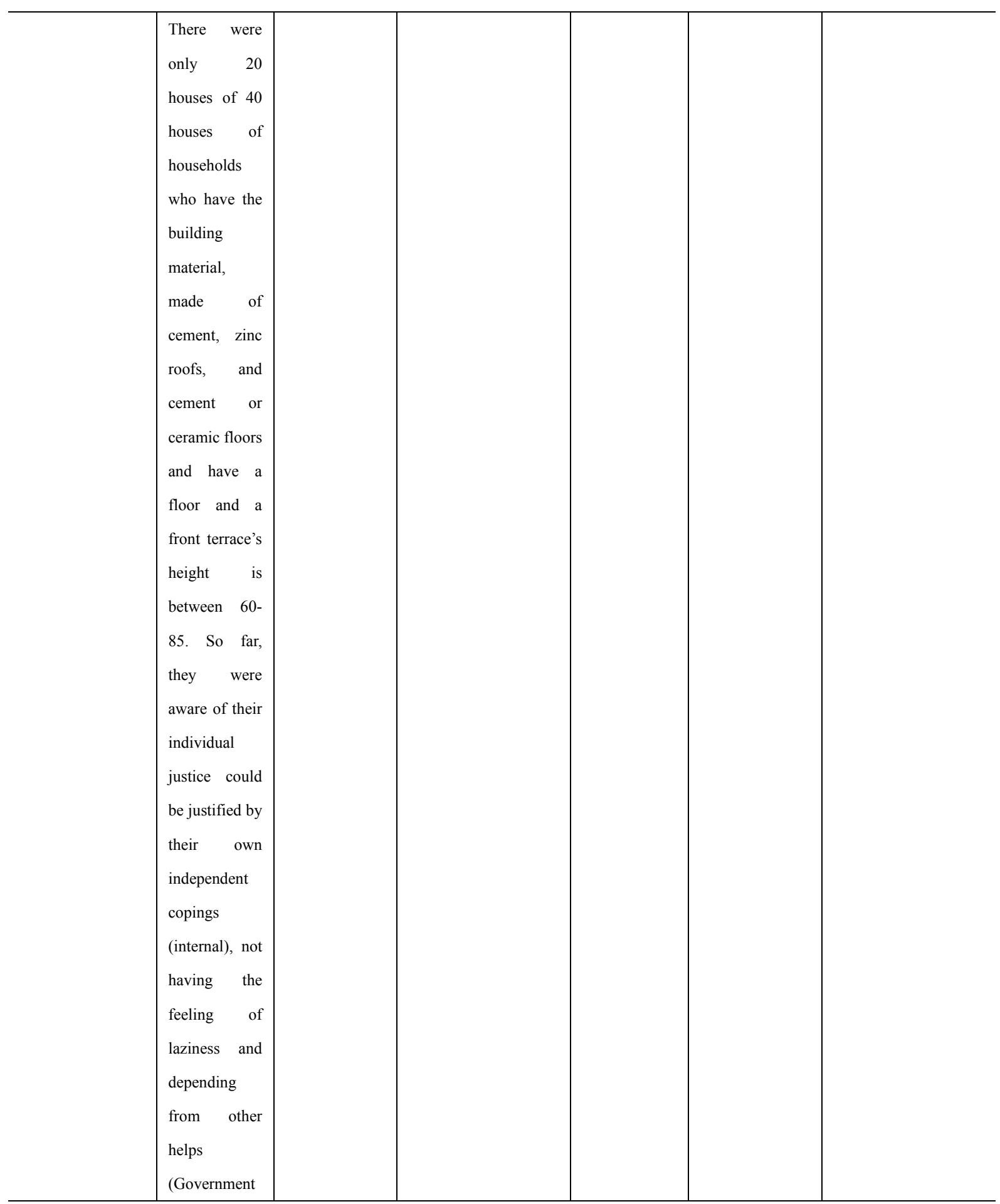

Source: Author's own data and assessment from the interview and FGDs (The fieldwork's result, 2012)

A2: The local community's adjustment processes can enhance their social and cultural copings for flood disaster if the mutual assistance is applied by them. This study illustrates these interrelationships into this Figure 13, "The Diagram of the Interrelationship between the Local Community's Adjustment Processes of Social and Cultural Copings" and Table 2 "Discussion and Assessment of this Diagram" based on the interview and FGDs with local community in Lasaen, Umatoos, and Fafoe villages are presented. 


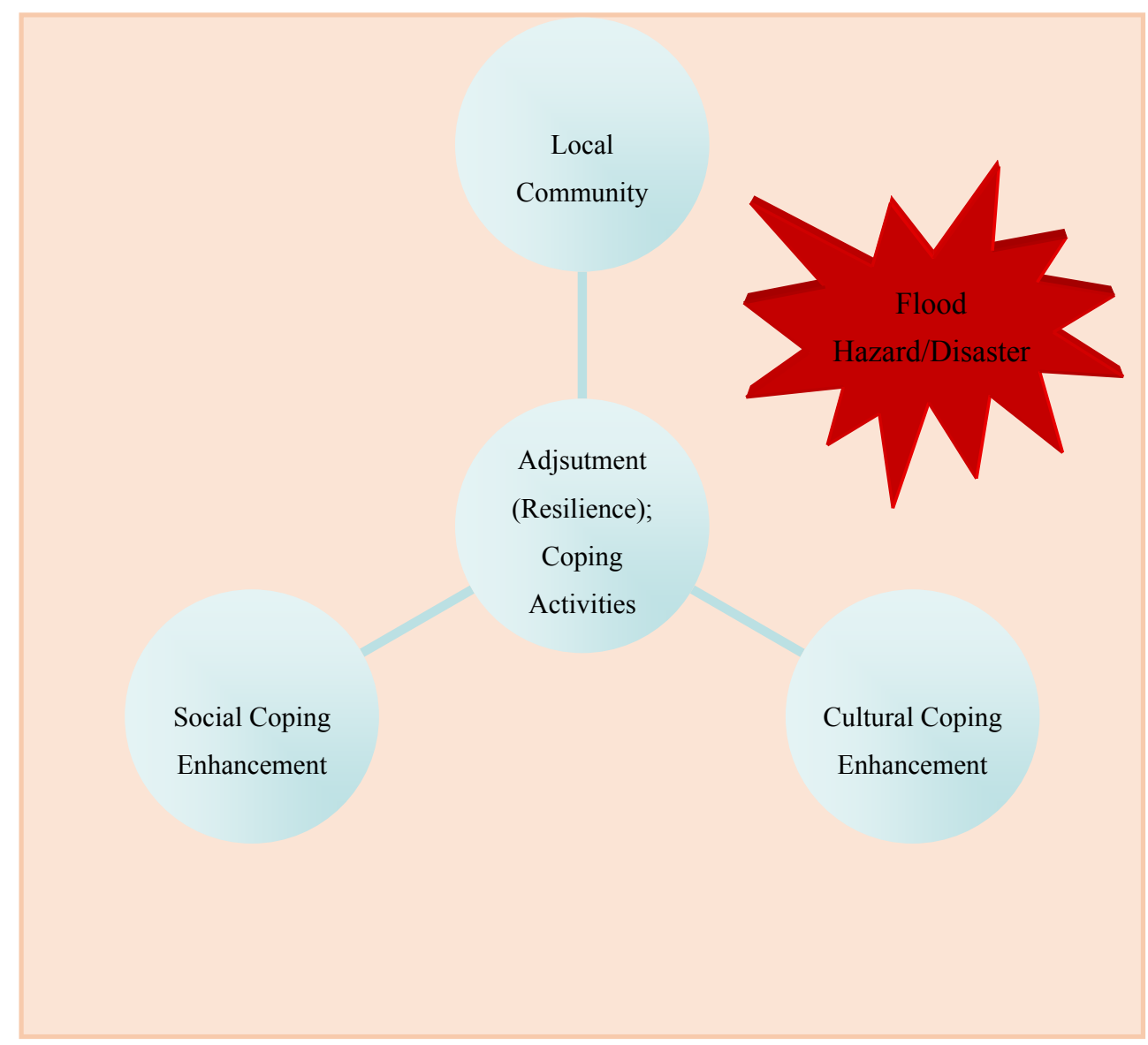

Figure 13. Diagram of the Interrelationship between the Local Community's Adjustment Processes of Social and Cultural Copings

Source: Author's own analysis of diagram

Table 2. Discussion and assessment of the diagram of the interrelationship between the local community's adjustment processes of social and cultural copings in Lasaen, Umatoos and Fafoe villages

\begin{tabular}{|c|c|c|c|c|c|}
\hline \multirow[b]{2}{*}{$\begin{array}{c}\text { Affected } \\
\text { villages } \\
\text { (Lasaen, } \\
\text { Umatoos, and } \\
\text { Fafoe) }\end{array}$} & \multicolumn{3}{|c|}{ Local community's risk perception } & \multicolumn{2}{|c|}{ Flood Hazard/Disaster } \\
\hline & $\begin{array}{l}\text { Social Coping } \\
\text { Enhancement }\end{array}$ & $\begin{array}{c}\text { Cultural Coping } \\
\text { Enhancement }\end{array}$ & $\begin{array}{l}\text { Applied-Adjustment } \\
\text { Processes }\end{array}$ & $\begin{array}{l}\text { Obstacles occurred in the short } \\
\text { term- and medium term }\end{array}$ & $\begin{array}{c}\text { Obstacles occurred in the medium } \\
\text { term and long-term }\end{array}$ \\
\hline Lasaen & $\begin{array}{l}\text { Slowly } \\
\text { implemented by } \\
\text { each twenty } \\
\text { households in this } \\
\text { village, but it was } \\
\text { sometimes } \\
\text { discontinued }\end{array}$ & $\begin{array}{l}\text { Moderately } \\
\text { implemented }\end{array}$ & $\begin{array}{l}\text { Social coping: } \\
\text { Nearly effective } \\
\text { mechanism in } \\
\text { understanding, } \\
\text { accommodating, but } \\
\text { not at the phase of } \\
\text { regulating, and } \\
\text { controlling the social } \\
\text { copingfully }\end{array}$ & $\begin{array}{l}\text { Social coping: } \\
\text { inter-and cross understanding } \\
\text { and communication among } \\
\text { community are frequently } \\
\text { ineffective. } \\
\text { Lasaen village has a short term- } \\
\text { and medium term (implemented } \\
\text { but not effective) } \\
\text { Cultural coping: }\end{array}$ & $\begin{array}{l}\text { Social coping: } \\
\text { Still need the process of optimizing } \\
\text { their social coping in the medium } \\
\text { term to long-term } \\
\text { Cultural coping: } \\
\text { Medium term-long term of cultural } \\
\text { coping enhancement. However, } \\
\text { currently, the health and food issue } \\
\text { have been a few problems in }\end{array}$ \\
\hline
\end{tabular}




\begin{tabular}{|c|c|c|c|c|c|}
\hline & & & $\begin{array}{l}\text { Cultural coping: } \\
\text { Effective mechanism in } \\
\text { understanding, } \\
\text { accommodating, and } \\
\text { controlling the cultural } \\
\text { coping's stability in } \\
\text { dealing with flood } \\
\text { disaster, but not } \\
\text { regulating }\end{array}$ & $\begin{array}{l}\text { Not belong to this level of } \\
\text { copings and has no obstacles in } \\
\text { response to flood hazard }\end{array}$ & $\begin{array}{l}\text { maximizing their coping to deal } \\
\text { with flooding. }\end{array}$ \\
\hline Umatoos & $\begin{array}{l}\text { Moderately } \\
\text { implemented }\end{array}$ & $\begin{array}{l}\text { Moderately } \\
\text { implemented }\end{array}$ & $\begin{array}{l}\text { Social coping: } \\
\text { Effective } \\
\text { Cultural coping: } \\
\text { Effective }\end{array}$ & $\begin{array}{l}\text { Social \& Cultural copings: } \\
\text { Not belong to this level of } \\
\text { copings and has no obstacles in } \\
\text { response to flood hazard }\end{array}$ & $\begin{array}{l}\text { Social coping: } \\
\text { inter-and cross understanding and } \\
\text { communication among community } \\
\text { are indeed effective. } \\
\text { Umatoos village has natural } \\
\text { resources i.e., fish and shrimp } \\
\text { ponds (seafoods) as its location is } \\
\text { at Abudenok estuary. The more } \\
\text { natural resources local community } \\
\text { have, the more social connection } \\
\text { they reached and implemented. A } \\
\text { group of fishing community was } \\
\text { established by the local fisherman } \\
\text { and this enhanced their social } \\
\text { coping. This village 's social } \\
\text { coping enhancement is indicated } \\
\text { as medium term (implemented but } \\
\text { not effective) } \\
\text { Cultural coping: } \\
\text { Medium term of cultural coping } \\
\text { enhancement. Due to its strategic } \\
\text { location nearby the estuary, some } \\
\text { external collaboration from other } \\
\text { society are difficult to reach and to } \\
\text { integrate with the local leaders } \\
\text { (culture's meeting, etc; cultural } \\
\text { coping). }\end{array}$ \\
\hline Fafoe & $\begin{array}{l}\text { Slowly } \\
\text { implemented }\end{array}$ & $\begin{array}{l}\text { Moderately } \\
\text { implemented }\end{array}$ & $\begin{array}{l}\text { Social coping: } \\
\text { Nearly effective } \\
\text { mechanism in } \\
\text { understanding, but not } \\
\text { at the phase of } \\
\text { accommodating, } \\
\text { regulating, and }\end{array}$ & $\begin{array}{l}\text { Social coping: } \\
\text { Remaining in the inter } \\
\text { understanding and } \\
\text { communication among } \\
\text { community } \\
\text { Fafoe village has a short term- } \\
\text { and medium term (implemented }\end{array}$ & $\begin{array}{l}\text { Social coping: } \\
\text { Remaining in the inter } \\
\text { understanding and communication } \\
\text { among community }\end{array}$ \\
\hline
\end{tabular}




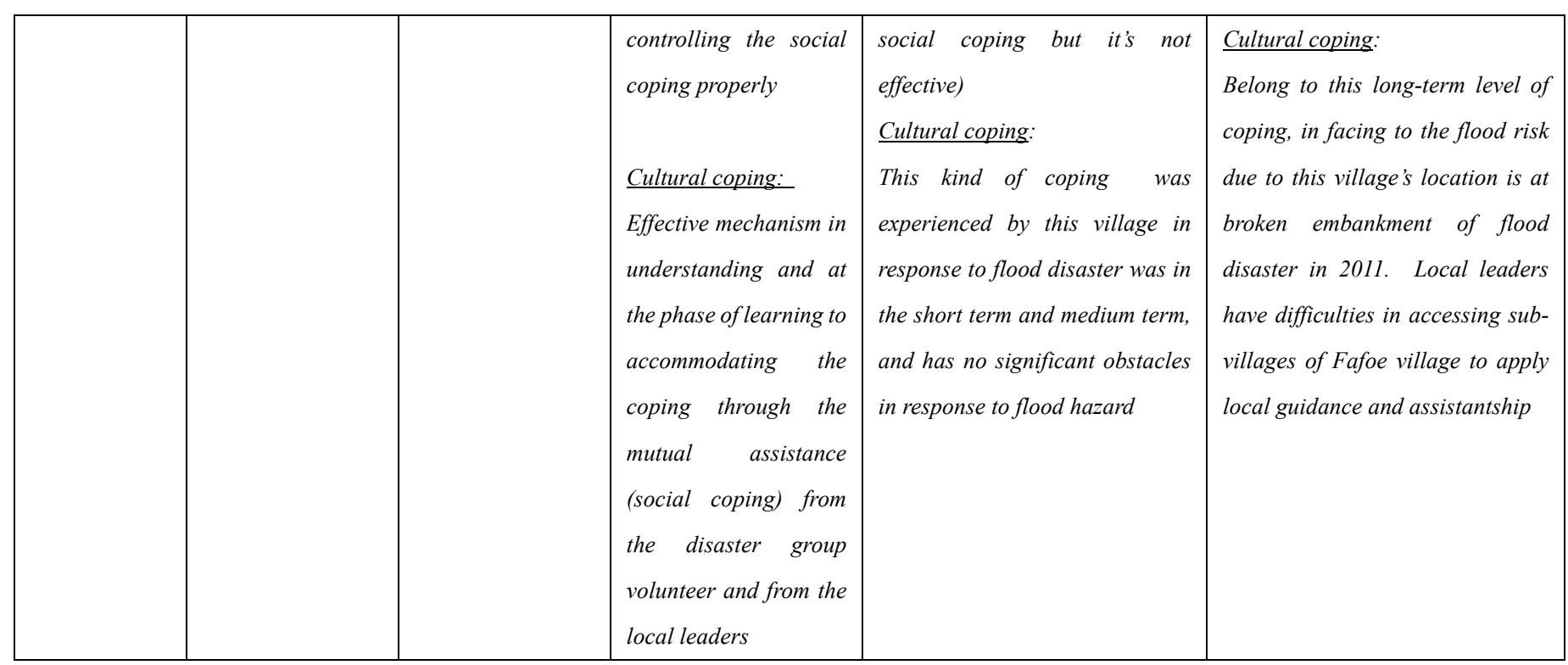

Source: Author's own data and assessment from the Interview and FGDs (fieldwork's result, 2012)

A3: The CMS could strengthen the social and cultural copings of the local community in facing flood disaster in a long process or period of time if the triangle of sub-CMS i.e., environmental policy, environmental communication, and social awareness from external society are implemented. This triangle of sub-CMS could effectively work in the medium through long term of sustainability copings. The specific interconnection between these three sub-conceptual models of CMS is presented in Figure 14 "The schematic of the understanding the interconnection copings from the triangle of sub-CMS (environmental policy, environmental communication, and social awareness)" and Table 3 "Discussion and assessment of this schematic" are presented below.

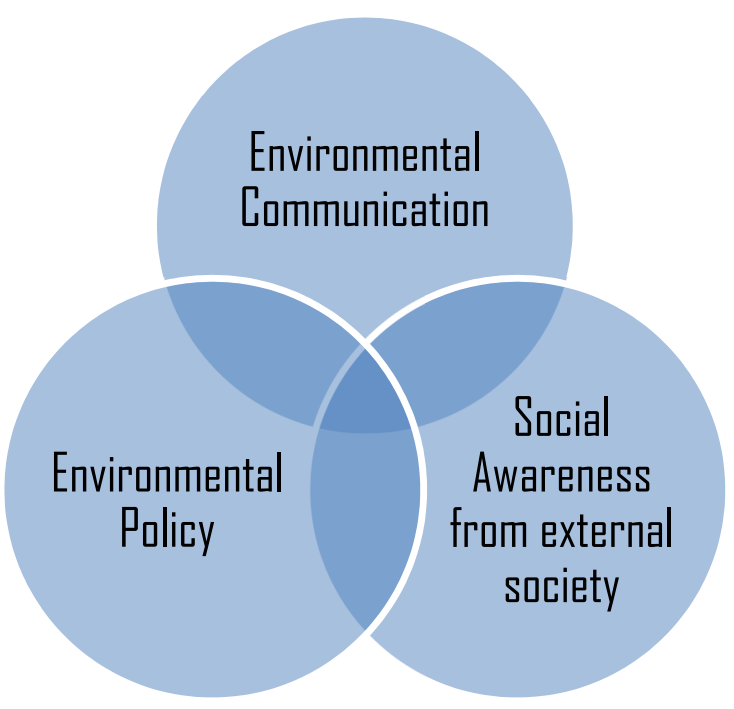

Figure. 14 The schematic of the understanding the interconnection copings from the triangle of sub-CMS (environmental policy, environmental communication, and social awareness)

Source: Author's own schematic 
Table 3. The understanding the interconnection copings from the triangle of sub-CMS (environmental policy, environmental communication, and social awareness)

\begin{tabular}{|c|c|c|c|c|}
\hline \multicolumn{3}{|c|}{ Understanding of the interconnection copings from the triangle of sub-CMS } & \multicolumn{2}{|c|}{$\begin{array}{l}\text { Strengthening/enhancing the social and cultural copings \& their } \\
\text { performance both short-medium term and in the medium-long term }\end{array}$} \\
\hline Environmental & Environmental Policy & Social Awareness from & Short-Medium Term & Medium Term and Long-Term \\
\hline Communication & & External Society & & \\
\hline Rolling system of risk & Lacking environmental & Limited from the external & Social coping: & Cultural coping: \\
\hline communication are still & policy from private and & society due to the accessibility & coping's & Cultural coping's performance is still \\
\hline based on individual justice & public Institutions at the & and transportation to reach & performance is still in & in medium-term to nearly long-term \\
\hline (initiative and decision) and & local, regional, and & the flattest area in & medium-term & \\
\hline individual coping (individual & national levels. The & downstream of Benanain & & Cultural coping's performance in \\
\hline ability to implement & implementation of & river i.e., Lasaen, Umatoos, & coping's & details: \\
\hline decision). This is the serious & monitoring and & and Fafoe villages & performance in details: & Cultural determination or resilience to \\
\hline matter in inter-connecting & controlling system of the & & The priority scale of local & cope with the barriers and challenges \\
\hline their sub-CMSs (social and & riverbank was not carried & & community in applying the & were encountered by local community \\
\hline cultural copings). Each & out by the private and & & mutual assistance to help & are less sufficient. Interconnection \\
\hline village can not reach flexibly & public Institutions at all & & each other are & between social coping and cultural \\
\hline other villages due to the long & levels. & & overlapping: $\quad$ However, & coping are strong and thus needing the \\
\hline duration offlood inundations & Decentralization in terms & & each coping was & transformation of copings. \\
\hline (flood's mud). Social and & to support the local & & implemented still binding & \\
\hline cultural copings copings & decision makers & & and dependent on one & \\
\hline were owned and & provide solutions or & & another & \\
\hline implemented by each & socialization & & & \\
\hline member of community over & empowering & & & \\
\hline three villages but not & resources and human & & & \\
\hline sufficient. & resources in the research & & & \\
\hline & site was not existed and & & & \\
\hline & effective in the long run & & & \\
\hline
\end{tabular}

Source: Author's own data and assessment from the Interview and FGDs (fieldwork's result, 2012)

A4: The cultural coping could be therefore considered as the main invaluable local coping of community in this discourse of sustainability's analysis. This discourse of sustainability and the invaluable copings are described through the trans-relationship and connection and its discussion and assessment which can be seen in the following Figure 15 "Chart of the Trans-Relationship and Connection between the Discourse-Unit of Sustainability and Invaluable Coping" and the presentation of Table 4 which discusses "Discourse and Analysis between Sustainability and Cultural Coping”. 


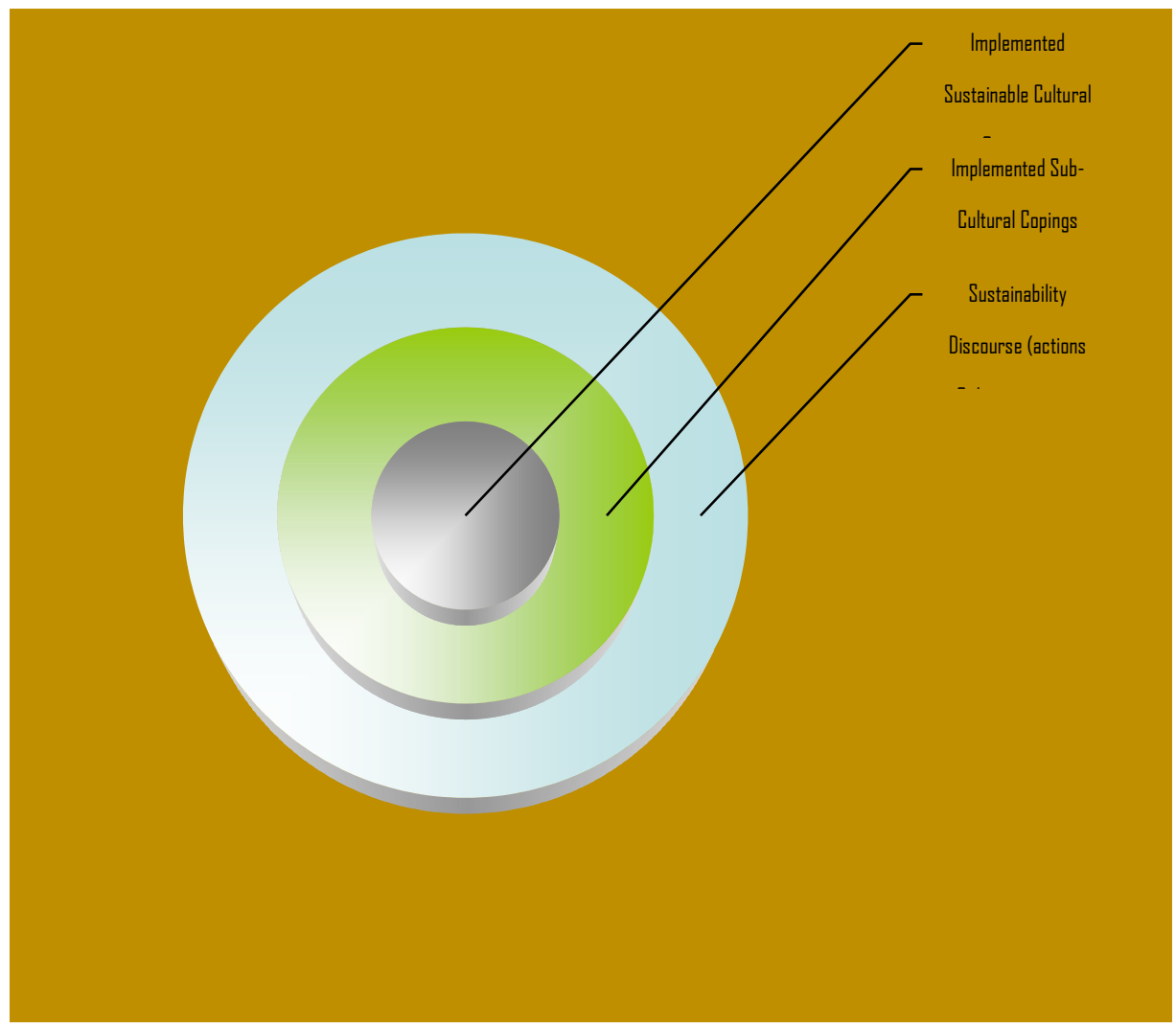

Figure 15. Chart of the Trans-relationship \& connection between the discourse-unit of sustainability and cultural coping

Source: Author's own analysis of chart

Table 4. Discourse and analysis between sustainability and cultural coping

\begin{tabular}{|c|c|c|c|c|}
\hline \multicolumn{3}{|c|}{ Trans-relationship \& connection between the discourse-unit of sustainability and cultural coping } & \multicolumn{2}{|c|}{ Discourse between the Medium-term and long-term } \\
\hline Connection between discourse- & Trans-connection of & Reconnection and recalling the & Effectiveness & Advisability \\
\hline unit of sustainability & discourse-unit of & sustainable cultural coping in the face of & Analysis & Analysis for the next flood season in the \\
\hline & sustainability as one unit & flood disaster & (medium term & future \\
\hline & of sustainable coping & & and long term) & (medium term and long term) \\
\hline Connections between discourse- & $\underline{\text { Trans-connection }}$ & The reconnection and recalling the & Trans- & Lesson learnt: $\quad$ sustainable cultural \\
\hline unit of sustainability i.e., & discourse-unit & sustainable cultural coping work out if & connection of & coping should be transformed its each \\
\hline historical values, civilization & sustainability: & this issue iimplements the combination of & discourse-unit & sub- abilities and values, in the \\
\hline values, cultural wisdom, and & Civilization & a helpful both the internal and external & of sustainability & discourse unit of sustainability, and \\
\hline compliance or obedience, & (maintain the good moral & transformable reciprocal relationship & as one unit of & should not be overlapped them without \\
\hline cultural rules, and cultural & or norm are insisted), & between civilization values and & sustainable & distributing the ability. \\
\hline beliefs are strong in living and & cultural rules, and & obedience; cultural rules with obedience; & coping & Conclusion: advisability of the unit of \\
\hline practicing in everyday life. & cultural beliefs & and cultural beliefs and cultural wisdom & civilization & sustainable cultural coping is medium \\
\hline However, a hazard situation such & transformed into cultural & and obedience. & values & term. \\
\hline as a flood makes a difference in & wisdom, but not into & transformable-reciprocal & (maintain & \\
\hline the implementation of cultural & compliance or obedience; & relationship could be strengthened from & good moral or & \\
\hline coping that was declined. It was & it has not meaning that & the initial and integrated actions (inter, & norms), cultural & \\
\hline not declined by their own & community's & cross and trans-copings to be sustainable) & wisdom, & \\
\hline
\end{tabular}




capacity that has been attempted disobedient these sub- $\begin{aligned} & \text { (See Figure } 14 \text { "The schematic of the compliance or } \\ & \text { to cope with flood hazard rather copings rather the understanding the interconnection obedience, }\end{aligned}$
by the external factors (society encountered the copings from the triangle of sub-CMS cultural rules,
and Institutions) in having difficulties of accessibility (environmental policy, environmental and cultural
solidarity in seeing and which were beyond their communication, and social awareness)" beliefs were not
understanding considerably this ability to cope with flood and Table 3 "Discussion and assessment still effectively
problem either as a crucial and a hazard.
priority for improvement or
neither both

Source: Author's own data, assessment, and analysis from the Interview and FGDs (fieldwork's result, 2012)

\section{Summary}

The flood frequency in the study area has similar time period that occurred in 1939, 1959, 1975, 1999 through 2000, and from 2000, its occurrence was happened each year until the present year, 2012. All sites in Lasaen, Umatoos, and Fafoe villages were inundated or flooded as the consequences of flood's risk that local community have to cope with, by utilizing their social and cultural copings. The flood characteristics i.e., flood frequency, flood extent and flood depth data were gathered through the interview and have shown that the information was similar with the FGD's result. The duration of flood inundation in Lasaen and Fafoe Villages based on FGD were also similar while Umatoos village was not. Flood inundation in Lasaen and Umatoos villages were starting from 0-7 days (minimum) until 14-21 days (maximum). Whereas, Fafoe village has to cope with longer days which was starting between 1 week and lasted at 1 month. According to interview from these three affected villages, the minimum longevity of flood duration was similar with the FGDs' data, while the exceed days of flood duration was different or taking longer days which was starting from 15 days and lasted at more than 21 days. For flood depth in Lasaen and Umatoos Villages through interview have the same zone depth's variation which was ranged from the lowest of water's depth that was from $0-50 \mathrm{~cm}$ until the deepest of water that was $251-300 \mathrm{~cm}$. Local community's understanding (risk perception) about their own social in response to the current flood hazard mapping assessment that they mapped using pGIS through FGDs and the result of interviews have shown that the informations and assessment were about individual justice-social networking, social rebound and affirmation, social connection and partnership: collective stimuli actions and emotions (psychological resilience/adjustment). Whilst cultural coping has sub-copings such as actualisation of the cultural power from every individual-social's belief, change and development (behavior change; habits nurtured as actions and copings), leadership female tribal chief and key local stakeholders) and traditions for moral values (intangible), and faith intervention (religion resilience/adjustment). The understanding the interconnection copings from the triangle of sub-CMS between the environmental policy, environmental communication, and social awareness concluded that environmental communication and environmental policy which were still lacking. There were still challenges or barriers to be coped with in cultural resilience, which this was less sufficient (medium-long term). The challenges or barriers which were experienced by local community were the unimplemented of transformation copings between social and cultural in CMS. Transformation of copings should be strengthened through the inter-cross connections between social coping and cultural coping. However, the overlapping mechanism in utilizing each sub-CMS for social and cultural copings was still existed. The positive performance of the CMS's analysis showing that the partnership and cooperative work were established to bind each type of copings. The combination of using the mix-methods and approaches i.e., Interviews, FGDs, pGIS, and CMS with risk perception and qualitative descriptive analysis was able to answer the flood problems and reveal several critical issues in discourse of sustainability copings. CMS was quite appropriate and relevant conceptual model to discuss and assess social and cultural copings in detailed.

\section{Acknowledgments}

The author is very grateful to the excellent scholarship (Beasiswa Unggulan: BU) provided by the Ministry of Education and Culture, Republic of Indonesia (grant's period, 2011-2013) who assisted her M.Sc study in ThreeSemester-International-Interdisciplinary Master Study Program, Geo-Information for Spatial Planning and Disaster Risk Management, Graduate School of Environmental Studies, Faculty of Geography, University of Gadjah Mada in Special Region of Yogyakarta, Central Java Province, Indonesia cooperated with the University of Twente, Enschede, The Netherlands ( $1^{\text {st }}$ September $2011-15^{\text {th }}$ February 2013). This research was part or one of 
former research objectives and research assessments from the author's M.Sc's Thesis that she has extended and updated some relevant theoretical supports and created a new conceptual model of CMS to be used on the assessment of coping in result and discussion sections. Meanwhile, Author is deeply thankful to Prof. Dr. rer. nat Muh Aris Marfai and Prof. Dr. M. Pramono Hadi from the Faculty of Geography, University of Gadjah Mada who were acting as the author's M.Sc supervisors in 2012-2013 and who gave their invaluable inputs and critics on completing this article. Finally, author thanks to all sixty affected households, female tribal chief of the Malaka's land, key local stakeholders especially Mr. Hironimus Ronny. Yoh. Seran SE, and Mr. Patrisius Seran Klau who involved, participated, and succeeded this empirical research in remote villages of river flooding i.e., Lasaen, Umatoos, and Fafoe, in the West Malaka Subdistrict of Belu Regency, in the Western Timor Island, East Nusa Tenggara Province, Indonesia.

\section{References}

Andriyani, M., Y., Al-Hidayah., Lestari, S., L, \& Ulifani, D., Z. (2010). Aplikasi Sistem Informasi Geografis (SIG) Kerawanan Bahaya Banjir DAS Bengawan Solo Hulu Berbasis Web. Geography Faculty, Muhammadiyah University. Surakarta.

BNPB, Badan Nasional Penanggulangan Bencana (The National Disaster Management Agency). (2011). Peta Wilayah Terkena Banjir di kabupaten Belu provinsi Nusa Tenggara Timur. Geospasial Badan Nasional Penanggulangan Bencana. Jakarta.

Dewi, A. (2007). Community-Based Analysis of Coping with Urban Flooding: A Case Study in Semarang, Indonesia. Gadjah Mada University. M.Sc Thesis. Library's Archives. International Institute for GeoInformation and Earth Observation. Enschede.

Environmental Agency of the British Government. (2005). The impacts of flooding on urban and rural communities. A report, product code. United Kingdom

Febrianti, F. (2010). Flood Risk Perception and Coping Mechanism of a Local Community: A Case Study in Part of Surakarta City, Central Java Province, Indonesia. Gadjah Mada University. MSc Thesis. International Institute for Geo- Information and Earth Observation. Enschede.

Frazer, J. (2010). Flood Frequency Analysis: International Edition. University Corporation for Atmospheric Research, The COMET Program and NOAA National Weather Service (NWS). USA. Retrieved from http://stream2.cma.gov.cn/pub/comet/HydrologyFlooding/FloodFrequencyAnaly sisInternationalEdition/comet/hydro/basic_int/flood_frequency/print.htm

IFRC, International Federation of Red Cross and Red Crescent Societies. (2011). Hydrological Hazards: General Floods and Flash Floods. IFRC's Publication. Geneva. Retrieved from http://www.ifrc.org/en/what-wedo/disaster-management/about disasters/definition-of-hazard/floods/

Info Nusa Tenggara Timur, NTT. (2011). Belu dalam Angka. Document. East Nusa Tenggara Province, Indonesia

Kabupaten Malaka. (2021, January 6). In Wikipedia. Retrieved from https://id.wikipedia.org/wiki/Kabupaten_Malaka

Kumar, U., Baten, M., A., Al-Masud, A., Osman, K., S., \& Rahman, M., M. (2010). Cyclone Aila: One Year on, Natural Disaster to Human Sufferings. Published by Unnayan Onneshan - The Innovators of Forest Peoples Programme. Bangladesh. Retrieved from http://www.forestpeoples.org/region/bangladesh/image/cycloneaila-one-year- natural-disaster-human-sufferings-report-unnayan-onn-0

Medscape. (2005). Types of Disasters and their consequences. American Public Health Association. USA. Retrieved from http://www.medscape.com/viewarticle/513258_8

Shah, S., A. (2012). Focus Group Discussions (FGDs) with Men and Women Beneficiaries from Communities: New Issues in Refugee Research After The Deluge: Gender And Early Recovery Housing In Sindh, Pakistan. Department of Sociology, University of Warwick. United Kingdom.

World Food Programme (WFP). (2016, March 17). In Flood-Affected Rural Areas, Poorest People Face Highest Food Insecurity Risk and Livestock and Fisheries Sectors yet to Recover from Severe Damage. WFP's news. Retrieved from https://www.wfp.org/news/myanmar-cyclone-struck-rural-areas-poorest-people-facehighest-food-insecurity-ris

World Meteorological Organization or WMO and The Global Water Partnership or GWP in The Associated Programme on Flood Management or APFM. (2008). A Tool for Integrated Flood Management. The Organizing Community Participation for Flood Management. APFM Technical Document No. 9, Flood 
Management Tools Series $\mathbb{C}$ The Associated Programme on Flood Management

Zein, M. (2010). A Community Based Approach to Flood Hazard and Vulnerability Assessment in Flood Prone Areas: A Case study in Kelurahan Sewu, Surakarta City, Indonesia. Gadjah Mada University. M.Sc Thesis. Library's Archives. International Institute for Geo-Information and Earth Observation. Enschede.

\section{Note}

Note 1. Lasaen, Umatoos and Fafoe villages were previously part of West Malaka Subdistrict of Belu Regency, in the Western Timor Island, East Nusa Tenggara Province (Provinsi Nusa Tenggara Timur or NTT), Indonesia. On December 14, 2012, Malaka Subdistrict of Malaka District was officially declared as the New Autonomous Region or District or Regency (Daerah Otonomi Baru or DOB) of the Law Draft, in the plenary session of The People's Representative Council, Republic of Indonesia (Dewan Perwakilan Rakyat, Republik Indonesia or DPR RI). This main empirical research was conducted at Lasaen, Umatoos, and Fafoe villages of West Malaka Subdistrict of Belu Regency, from July $31^{\text {st }}$ until August $31^{\text {st }} 2012$. This period of the empirical research was accomplished three months prior to the DOB for the West Malaka Subdistrict as the new administrative territory of Malaka Regency which was implemented in December 14, 2012.

Kabupaten Malaka (2021, January 6). In Wikipedia (See https://id.wikipedia.org/wiki/Kabupaten_Malaka)

\section{Copyrights}

Copyright for this article is retained by the author(s), with first publication rights granted to the journal.

This is an open-access article distributed under the terms and conditions of the Creative Commons Attribution license (http://creativecommons.org/licenses/by/4.0/). 